\title{
Structural evolution of continental and marine Permian rock salt of the North German Basin: constraints from microfabrics, geochemistry and $\mathrm{U}-\mathrm{Pb}$ ages
}

\author{
Mareike Henneberg ${ }^{1}$ (D) Jolien Linckens ${ }^{2} \cdot$ Michael Schramm $^{1} \cdot$ Jörg Hammer ${ }^{1} \cdot$ Axel Gerdes $^{2,3}$ (D) Gernold Zulauf ${ }^{2}$
}

Received: 8 April 2020 / Accepted: 28 June 2020 / Published online: 9 August 2020

(C) The Author(s) 2020

\begin{abstract}
Analyzing the dynamics of microstructural response on natural deformation in rock salt, we present microfabric, EBSD, geochemical and $\mathrm{U}-\mathrm{Pb}$ data, obtained from Permian salt formations of the Kiel-Honigsee salt wall in Northern Germany. The samples were recovered from deep drillings, which penetrated through an overturned rock salt sequence of both Rotliegend and Zechstein deposits. The bromide concentration in halite indicates a continental and marine origin for the Rotliegend and Zechstein deposits, respectively. Despite intense deformation, relics of early diagenetic fabrics are still preserved. Deformation of the impure Rotliegend rock salt was accommodated by pressure solution and hydrofracturing as is indicated by the microfabrics and bromide concentration in halite. Fractures in siliciclastic domains were filled with fibrous halite and deformed by subgrain rotation recrystallization (SGR). Fluid-rich Zechstein rock salt, on the other hand, was deformed by formation of subgrains and grain boundary migration (GBM). The distribution of mineral phases and fluids had a significant impact on the fabric evolution and on strain localization. U-Pb dating of carbonate phases of the Rotliegend sequence yielded Permian depositional ages and Jurassic to Cretaceous deformation ages, the latter related to diapiric ascent. The combination of results traces a dynamic evolution of the rock fabric inside the diapir structure driven by locally active deformation processes that can be correlated with early stages of halite deposition and diagenesis and syntectonic fabric reorganization related to diapirism in an extensional setting.
\end{abstract}

Keywords Rock salt $\cdot$ Halite $\cdot$ Microstructures $\cdot$ Diapirism $\cdot$ North German Basin $\cdot$ Evaporite $\cdot$ Geochemistry $\cdot \mathrm{U}-\mathrm{Pb}$ dating

\section{Introduction}

Salt diapirs consist of various types of salt rocks, comprising halite and non-halite evaporites, which differ not only in composition, but also in effective viscosity (Borchert and

Deceased: Jörg Hammer.

Electronic supplementary material The online version of this article (https://doi.org/10.1007/s00531-020-01905-w) contains supplementary material, which is available to authorized users.

Mareike Henneberg

mareike.henneberg@bgr.de

1 Bundesanstalt für Geowissenschaften und Rohstoffe (BGR), 30655 Hannover, Germany

2 Institut für Geowissenschaften, Goethe-Universität Frankfurt am Main, 60438 Frankfurt am Main, Germany

3 Frankfurt Isotope and Element Research Center (FIERCE), Goethe-Universität Frankfurt am Main, 60438 Frankfurt am Main, Germany
Muir 1964; Raith et al. 2016; Rowan et al. 2019). The difference in viscosity of individual layers is related to the deposition and diagenesis of the sedimentary evaporitic sequence. Such rheologically stratified rocks show inhomogeneous deformation, because the strain rate is higher in the incompetent (lower viscous) beds than in the competent (higher viscous) beds resulting in folds, boudins and mullions (e.g., Schmalholz and Mancktelow (2016) and references therein).

Most salt diapirs include large amounts of 'rock salt', a term that is commonly used for all rocks composed of mostly halite (Hudec and Jackson 2007). If rock salt is interbedded with anhydrite, the latter is forming the competent layer, whereas rock salt is forming the incompetent matrix (e.g., Bornemann et al. 2008; Zulauf et al. 2010; Zulauf et al. 2009). On the other hand, rock salt may form a competent layer if surrounded by weaker incompetent carnallite matrix (Richter-Bernburg 1955; Siemeister 1969). Moreover, the viscosity ratio between layers of different competence can vary gradually in salt rocks by changing the amount of dispersed competent phases in the weaker matrix (Hunsche 
2003; Jordan 1987; Závada et al. 2015). In the Louann salt in the Gulf Coast of Mexico, layers with only slightly higher (4-5\%) dispersed anhydrite content are prone to folding in halite matrix (Muehlberger and Clabaugh 1968).

In Northern Germany, not only the marine late Permian Zechstein evaporite sequences, but also the older evaporitebearing Rotliegend rocks were detached and carried upwards during diapirism. Therefore, Rotliegend salt rocks are also parts of the recent salt walls and diapirs (Fig. 1c). Starting with the formation of the Glückstadt Graben in early
Mesozoic times, the salt sequence underwent several phases of deformation during diapiric ascent (Maystrenko et al. 2005b, 2016; Warsitzka et al. 2016).

Parts of the Upper Rotliegend sequence are heterogeneous in composition. They consist of rock salt and reddish siliciclastic sediments deposited in the Southern Permian Basin (SPB) during the early formation stages of the North German Basin (NGB). Mixtures of rock salt and siliciclastic components are common in this sequence. Diapirism led to internal deformation of the Rotliegend and Zechstein
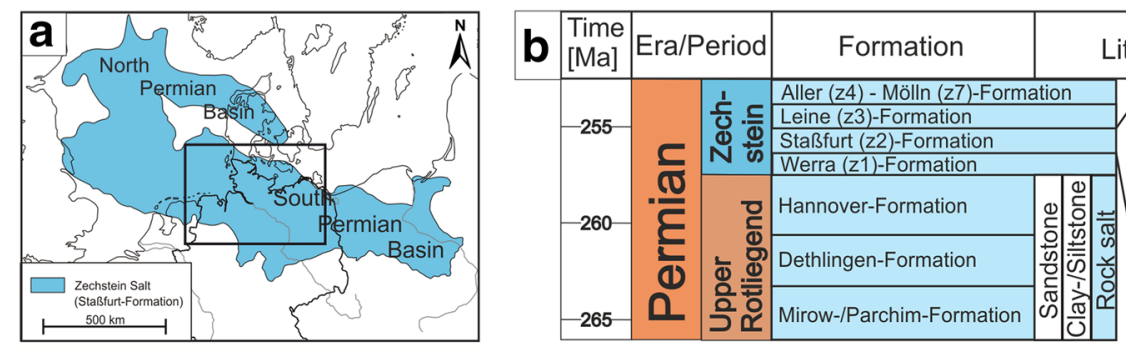

Lithostratigraphy
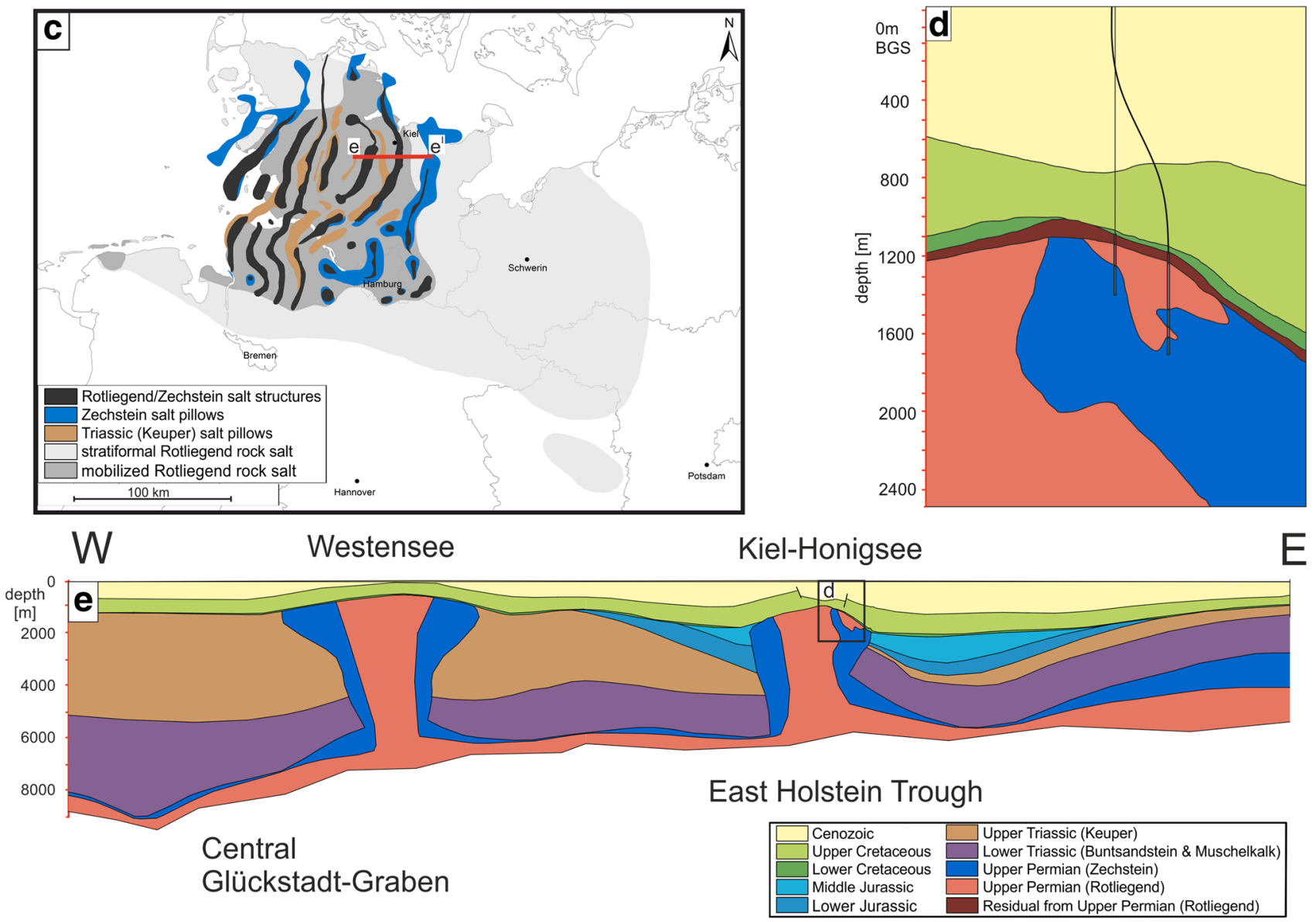

Fig. 1 Geological maps and cross sections of the study area. a Zechstein salt distribution in the North and South Permian Basin after Best (1989) and Küster et al. (2009). b Lithostratigraphic section showing investigated rock salt units (after SKPT (2011); Baldschuhn et al. (2001); Bornemann et al. (2008)). c Salt structures in Northern Germany that contain mobilized Rotliegend and Zechstein rock salt (after Pollok et al. (2020); Reinhold and Hammer (2016)). d View of the Eastern flank of the Kiel-Honigsee structure showing the internal structure and the position of the two investigated drillings. For location see insert in e. e W-E cross section of the Eastern Glückstadt Graben (modified after Baldschuhn et al. (2001); Hese et al. (2016)). The location of the cross section is indicated as e-e' in c 
sequences resulting in an overturned fold limb in the KielHonigsee salt wall where Rotliegend and Zechstein rocks are juxtaposed (Fig. 1d). This juxtaposition allows to pinpoint the difference in the rheological behavior of Zechstein rock salt (main salt, z2HS) and mixtures of rock salt and siliciclastic components of the Rotliegend strata. We have investigated such rocks in two deep boreholes that have been drilled through the overturned Rotliegend sequence, ceasing in the Zechstein rock salt. Our studies were focusing on macroscopic fabrics, microstructures, textures, radiometric ages and geochemistry. The new data are used to unravel the structural evolution and to constrain the conditions and age of deformation.

\section{Geological setting}

The deposition of rock salt in the Upper Rotliegend marks the onset of extensive episodic evaporite buildup throughout the NGB. After early Permian magmatism had ceased, rapid subsidence resulted in the formation of the SPB as part of the Central European Basin system (CEBS) (Bachmann et al. 2008; Geluk 2005; McCann et al. 2008; Van Wees et al. 2000) (Fig. 1a). Upper Rotliegend successions are characterized by continental reddish alluvial, fluvial, playa and salt lake fining-upward sediments of up to $2000 \mathrm{~m}$ in thickness (Bachmann et al. 2008; Stollhofen et al. 2008). A playa system developed under arid conditions with the depositional center located in Northern Germany (Gaupp et al. 2000; Legler et al. 2005; Plein 1993; Stollhofen et al. 2008). The depositional style of a closed continental basin allowed for the deposition of halite in the deepest part of the basin during dry periods (Gast et al. 2010; Katzung 1991). Subsequent to the Zechstein transgression, the sequences were superposed by the marine evaporitic Zechstein series. The initial thickness of the Permian salt rock sequence at the flanks of the Glückstadt Graben is estimated between 1300 and $1900 \mathrm{~m}$ (Maystrenko et al. 2005b).

After late Permian and early Triassic tectonic quiescence, the SPB was affected by normal faulting related to the early Triassic formation of the Glückstadt Graben. The structural evolution was driven by rapid subsidence and several phases of diapirism related to the tectonic evolution of the CEBS (Kley et al. 2008; Maystrenko et al. 2005a, b; Warsitzka et al. 2016). While the thickness of Triassic sediments is $>6500 \mathrm{~m}$ in the central Glückstadt Graben, the thickness is much lower at the basin flanks and marginal troughs ranging from 1300-2300 m (Maystrenko et al. 2006, Fig. 1e).

The Kiel-Honigsee structure is part of a salt wall that in its northern part strikes approximately NW-SE. The structure belongs to the East Holstein Trough, which is located at the eastern periphery of the Glückstadt Graben (Maystrenko et al. 2005a, 2017). Due to its location at the eastern rim of the Glückstadt graben, at the contact to the tectonically quieter East Holstein Trough, the structure shows an asymmetric evolution with respect to the peripheral sinks (Warsitzka et al. 2016): the evolution of the Kiel-Honigsee structure started in Early Triassic times (Buntsandstein) as deduced from thickening of peripheral sinks at the western flank. Maximum growth of the structure occurred in the Middle Triassic from late Buntsandstein to middle Jurassic times, which led to sedimentation of thickened Jurassic peripheral sinks (Maystrenko et al. 2005a). The strongest phase of salt structure growth occurred in early Jurassic times as calculated from the depth of the peripheral sinks (Warsitzka et al. 2016). A second phase of diapirism was active from the middle Cretaceous with consistent growth of the salt structure throughout the Cenozoic as shown by regional sedimentation patterns (Maystrenko et al. 2017) (Fig. 1e).

\section{Materials and methods}

\section{Collected samples}

Samples were prepared from two separate boreholes (Kiel 101 and Kiel 102) that were drilled in the eastern flank of the Kiel-Honigsee structure (Fig. 1d, e) to final depths of 1500 and $1805 \mathrm{~m}$ (Beutel and Folle, unpubl. report). Both drillings intersect Rotliegend rock salt inside the diapir structure, before the contact to Zechstein rock salt is reached. Internal folding of the Rotliegend-Zechstein sequence is indicated by drilling Kiel 102 crosscutting two different sections of Rotliegend rock salt. Directional drilling led to a total horizontal offset of $300 \mathrm{~m}$ in the drilling. The investigated boreholes cover a depth interval from 1277 to $1763 \mathrm{~m}$. Samples were taken from 57 core sections that were drilled to a diameter of $10 \mathrm{~cm}$. The drilled core sections comprise Rotliegend rock salt mixed with red- to brown-coloured siliciclastic components and clear to milky Zechstein halite with a grey to white colour. Samples were taken from halved and polished drill core crosscuts.

\section{Microfabric analysis}

Thin and thick sections of drill cores were investigated by transmitted light microscopy. For detailed imaging of the siliciclastic domains, a FEI Quanta 600 FEG ESEM was used; phase analyses were carried out with a coupled EDXdetector (EDAX Apollo XL).

Electron backscatter diffraction (EBSD) analyses were performed on thick sections cut perpendicular to the long axes of halite fibers close to the phase boundary from 
halite to siliciclastic domains. For visualization of subgrain structures, polished thick sections were etched for $40-50 \mathrm{~s}$ with an unsaturated (5.5 molar) $\mathrm{NaCl}$ solution and cleaned with n-hexane using the method described by Urai et al. (1987).

The crystallographic orientation of halite fibers in areas of high strain, inferred by grain shape preferred orientation, was measured over large areas. The analyses were performed using a JEOL JSM-6490 scanning electron microscope with an acceleration voltage of $\sim 15 \mathrm{kV}$ and a beam current of $\sim 7 \mathrm{nA}$. The step size was between 5 and $100 \mu \mathrm{m}$ depending on the measured area.

The data were processed using the Oxford Channel 5 Software. On the EBSD maps, filtering included removal of isolated misindexed points ("wild spikes"), removal of zero solutions with the predominant orientation of minimum four indexed neighbors and application of a Kuwahara filter, which averages the orientation of $3 \times 3$ pixels. Additionally, equal-area, upper hemisphere pole figures were generated in order to show the distribution of lattice orientation over the measured area. Misorientation profiles were generated to show the degree of misorientation over single subgrain boundaries.

\section{Geochemical analysis}

Sample material for bulk analysis of evaporite phases was available from sawed rock slices. For detailed sampling of halite, drill cuttings were retrieved from polished core sections representing an area of $1 \mathrm{~cm}^{2}$ resulting in a total of $1 \mathrm{~g}$ of sample material.

For geochemical analyses of the water-soluble rock content, powder samples were investigated by Inductively Coupled Plasma Optical Emission Spectroscopy (ICPOES), using a Spectro CIROS ICP-OES. The samples were dissolved in double-distilled $\mathrm{H}_{2} \mathrm{O}$ and the anions and cations were analyzed by quintuple measurement. For the main geochemical components $\mathrm{Na}^{+}, \mathrm{Cl}^{-}$and $\mathrm{SO}_{4}{ }^{2-}$, the analytical uncertainty is $\pm 1 \%$. The detection limit for bromide is $2 \mathrm{ppm}$ with an accuracy of measurement of $\pm 5 \%$.

The quantitative mineralogical composition was calculated using the ZECHMIN-7 software (Bornemann et al. 2008) from the ion contents obtained by ICP-OES measurements. The calculated mineral contents have an uncertainty of $\pm 1 \mathrm{wt} \%$; bromide contents in halite can be calculated with an accuracy of $\pm 5 \%$.

For the samples obtained from detailed sampling of halite, the main geochemical components $\mathrm{Na}^{+}, \mathrm{K}^{+}$and $\mathrm{SO}_{4}{ }^{2-}$ and $\mathrm{Br}^{-}$were analyzed by ICP-OES measurement using the method described above. Samples that contained more than 97 wt. \% halite based on their $\mathrm{Na}^{+}$- concentrations were evaluated for their bromide concentrations.

\section{$\mathrm{U}-\mathrm{Pb}$ age dating of carbonate phases}

Analyses were performed using a Thermo Scientific Element XR sector field ICP-MS, coupled to a RESOlution (Resonetics) $193 \mathrm{~nm}$ ArF Excimer laser (CompexPro 102, Coherent) equipped with a S-155 two-volume ablation cell (Laurin Technic, Australia). Samples were ablated in a helium atmosphere $(0.3 \mathrm{l})$ and mixed in the ablation funnel with argon (1 1$)$ and nitrogen $(8 \mathrm{ml})$. Analyses were performed with a squared ablation spot of $213 \mu \mathrm{m}$ in diameter, $8 \mathrm{~Hz}$ frequency and fluence of around $2 \mathrm{~J} \mathrm{~cm}^{-2}$. A manual prescreening session allowed identifying areas with variable $\mathrm{U} / \mathrm{Pb}$ ratios.

$\mathrm{U}-\mathrm{Pb}$ ages were acquired from 10 to 49 single analyses per sample. Sample spots were preablated for $3 \mathrm{~s}$ to remove surface contamination, followed by $20 \mathrm{~s}$ of background acquisition, $30 \mathrm{~s}$ of sample ablation and $20 \mathrm{~s}$ washout. WC-1 (Roberts et al. 2017), NIST SRM 614 (Woodhead and Hergt 2001) and three internal standards were used during measurement.

Raw data were corrected off-line using an in-house MS Excel spreadsheet program (Gerdes and Zeh 2006, 2009). Fractionation of ${ }^{206} \mathrm{~Pb} /{ }^{238} \mathrm{U},{ }^{207} \mathrm{~Pb} /{ }^{206} \mathrm{~Pb}$ mass bias and the drift during the analytical session was corrected based on repeated analyses of soda-lime glass NIST-SRM 614. WC-1 calcite (Roberts et al. 2017) was used to correct for matrix offset (9\%) between NIST glass and carbonate. Data were plotted in Tera-Wasserburg diagrams and all uncertainties are reported at the $95 \%$ confidence level.

\section{Results}

\section{Fabric analysis}

\section{Rotliegend sequence}

The studied Rotliegend rocks consist of both siliciclastic and halitic components. Relatively large halite crystals $(5-40 \mathrm{~mm})$ are present in different halite fabric types:

Euhedral-to-subhedral halite crystals with large grain sizes of up to $40 \mathrm{~mm}$ build up large areas of the halite-dominated domains. Depending on its amount, they are either entirely entrapped in siliciclastic matrix or they are part of a coarse grained rock fabric with up to $90 \%$ halite and $10 \%$ siliciclastic components, the latter distributed mostly at halite grain boundaries (Fig. 2a). Areas with high local content of siliciclastic material usually contain displacive euhedral-to-subhedral halite crystals (Fig. 2b). Areas with lower amounts of siliciclastic components show isometric grains of halite, which are characterized by a xenomorphic shape and lobate grain boundaries. Bedding is preserved in single siliciclastic domains as indicated by changes in color 

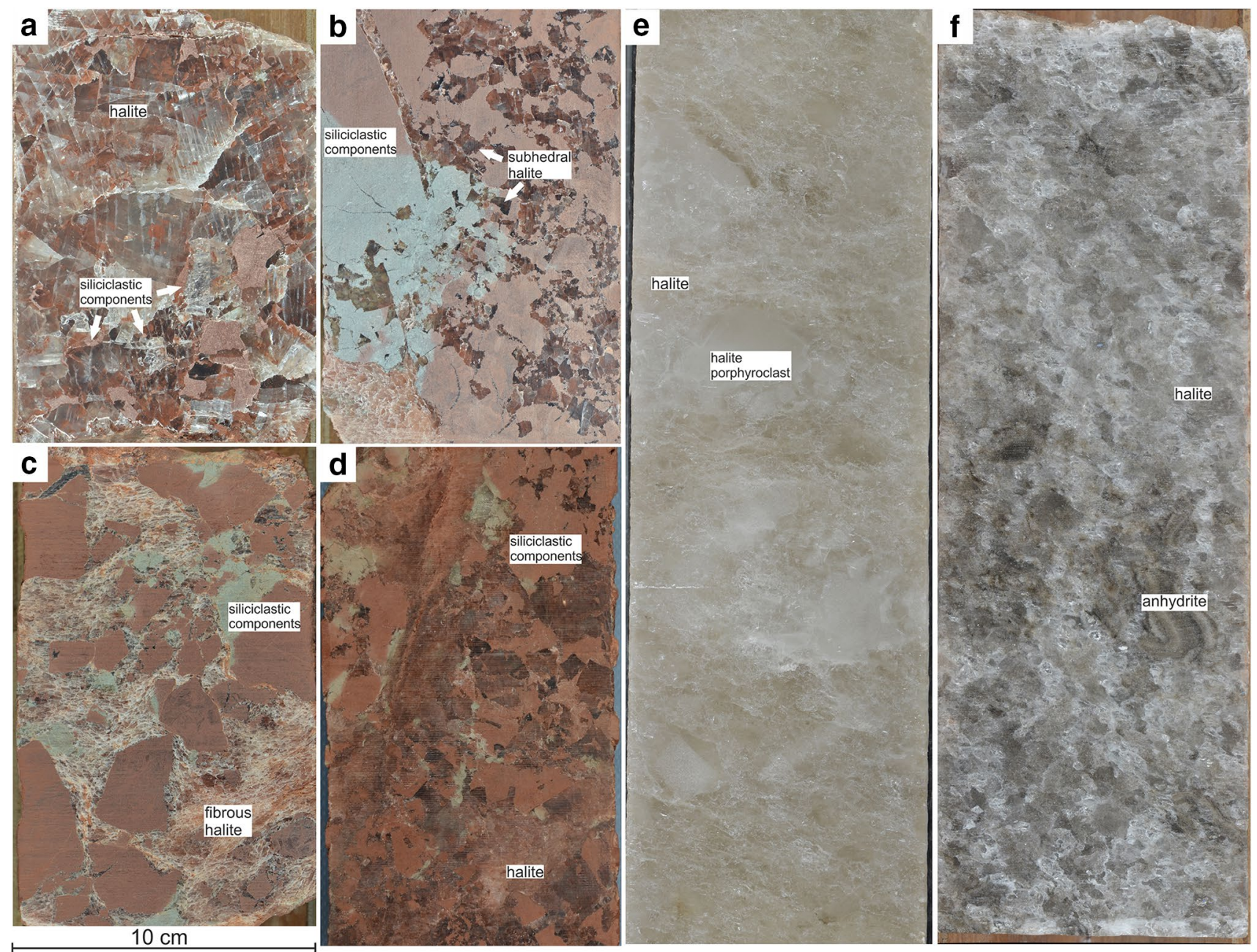
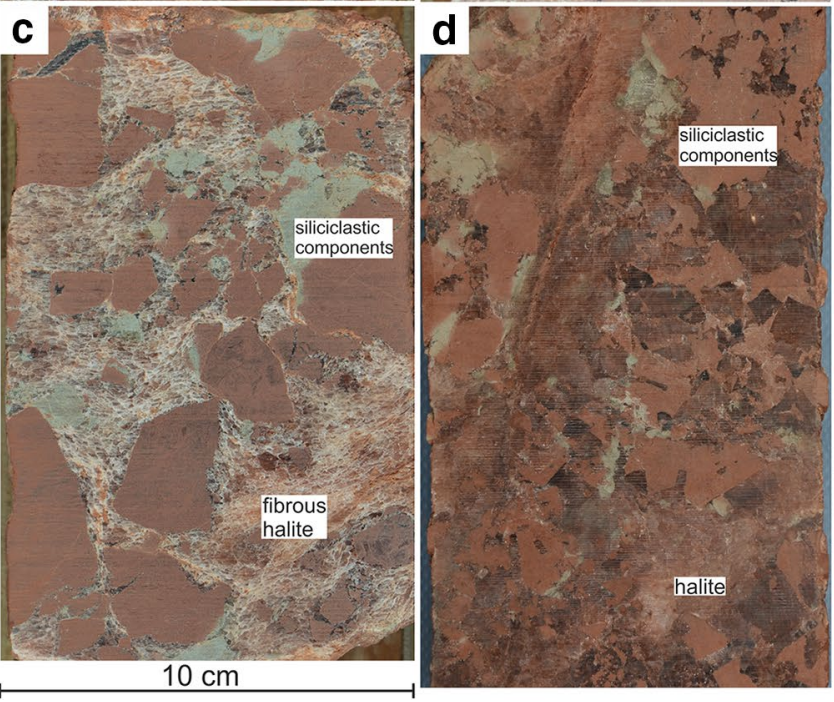

Fig. 2 Polished drill core crosscuts of Rotliegend (a-d) and Zechstein $(\mathbf{e}, \mathbf{f})$ rock salt. The scale represents the size for all core sections. a Coarse-grained, equiaxed halite grains with dispersed siliciclastic components. Kiel 102, 1416 m. b Subhedral halite crystals in siliciclastic matrix. Note local green bleaching of siliciclastic domains. Kiel 102, 1379 m. c Fibrous halite surrounding angular siliciclastic

and grain size. Fractures filled with halite crosscut siliciclastic domains showing a random orientation.

Locally, a strong shape-preferred orientation (SPO) of halite is related to fibrous crystals, which are present either as fracture infill or as halite matrix surrounding single clasts of siliciclastic material (Fig. 2c). The fractures are characterized by changing orientation of halite grain elongation, while the rimming siliciclastic domains preserve sharp outlines. This also applies for halite infill of larger fractures, which preserve centimeter-sized halite fibers. These fibers show a gradual change in orientation pointing to a change in the opening direction of the fractures. The fractures do not show a preferred orientation. Generally, the habitus of halite fabric changes locally according to the distribution of siliciclastic material. Close interrelation of different halite components. Kiel 102, 1376 m. d Irregular distribution of siliciclastic and halitic components with preservation of subhedral and fibrous halite crystals. Kiel 101, 1292 m. e Large, partly elongated "Kristallbrocken" porphyroclasts in coarse grained halite matrix. Kiel 102, $1645 \mathrm{~m}$. f Anhydrite clusters in halite matrix displaying a weak SPO. Kiel 102, 1605 m

types described above (euhedral/subhedral, xenomorphic and fibrous) is common (Fig. 2b, d).

\section{Zechstein sequence}

Zechstein strata preserve clear to cloudy halite crystals of a white to grey color. The lithology represents the upper two stratigraphic units of the Staßfurt Main Salt (z2HS), the "Streifensalz" (z2HS2) and "Kristallbrockensalz" (z2HS3), which are common in salt structures of the central NGB (Bornemann et al. 2008; Küster et al. 2009). Rock salt includes halite with impurities of anhydrite and minor content of polyhalite and microcrystalline carbonate. Larger clusters of anhydrite up to $20 \mathrm{~mm}$ in size reflect an internal layering that is characterized by local enrichment of 
carbonate and small fractions of siliciclastic material. The lithology of the "Kristallbrocken" (z2HS3) is characterized by inclusion-rich halite porphyroclasts (Figs. 2e, 3a) and are interpreted to have originated from a monocrystalline halite layer of diagenetic origin that has been deformed during salt structure formation (Küster et al. 2010). Apart from the coarse-grained "Kristallbrocken" salt, the halite matrix is characterized by a homogenous average halite grain size of $5 \mathrm{~mm}$; some areas show a weak SPO (Fig. 2f). Apart from anhydrite clusters, where microcrystalline anhydrite is common (Fig. 3e), anhydritic and polyhalitic phases are distributed along halite grain boundaries, where anhydrite is present as subhedral and lath-shaped crystals (Fig. 3d). Polyhalite is preserved as large crystals up to $0.5 \mathrm{~mm}$ in size which show typical cross-shaped twinning and an irregular crystal outline. Halite inclusions in polyhalite represent a coeval evolution of the polyhalite and halite phase (Fig. 3f).

\section{Microstructures of halite and detrital components}

Subgrains used as paleopiezometer in halite have been reported to reflect similar differential stresses (1.1-1.5 MPa) throughout both Rotliegend and Zechstein strata (Henneberg et al. 2018). In the Rotliegend strata, subgrains are developed throughout different halite fabric types regardless of local content of detrital material (Fig. 4c). Grain boundaries of halite are decorated with fluid inclusions. Elevated amounts of fluid inclusions can be observed at the grain contacts of halite fibers (Fig. 3a, d). Intracrystalline fluid inclusions are absent, while subhedral, large halite crystals sometimes preserve smaller inclusions of siliciclastic components.

In the Zechstein strata, euhedral subgrain-free grains occur, surrounded by subgrain rich grains (Fig. 3c). Due to the large number of euhedral grains, the fabric is dominated by serrated grain contacts (Fig. 3a, b). In contrast to the Rotliegend rocks, fluids in the Zechstein strata can be found at grain boundaries as well as inside halite crystals (Fig. 3b). Intracrystalline fluids in Zechstein rock salt can even be observed inside euhedral halite crystals, which are free from subgrains (Fig. 3c).

Detrital components are forming the reddish homogeneous fine-grained sedimentary matrix in the Rotliegend strata. Locally preserved sedimentary layers or anhydrite nodules indicate the formation of initially halite free sequences (Fig. 4f). The reddish coloration is often disrupted by irregular bleaching patches, up to $5 \mathrm{~cm}$ in size pointing to local changes of the redox state in the sediment (Fig. 2b-d). Such bleaching is often related to halite filled fractures in the siliciclastic matrix.
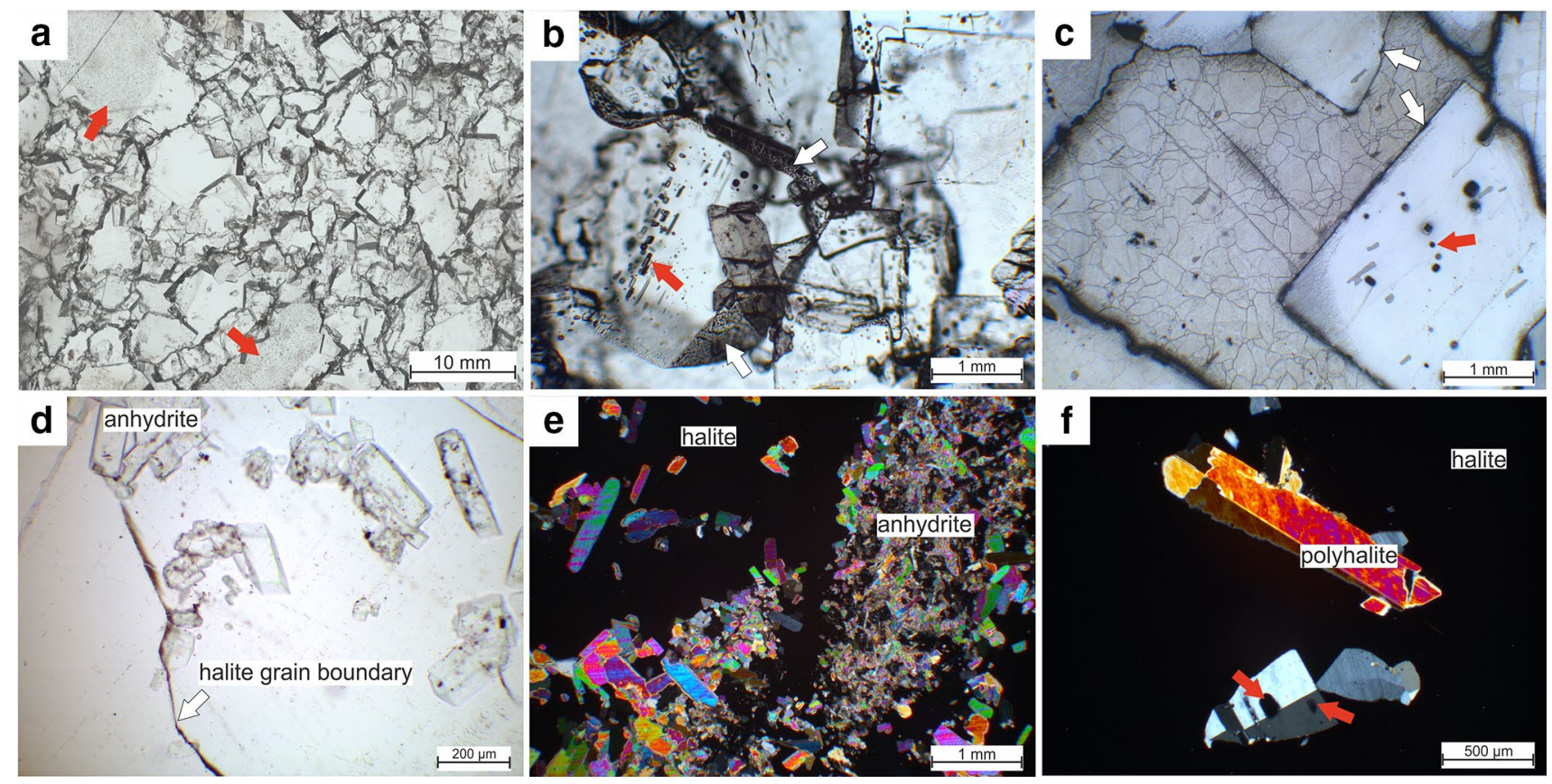

Fig. 3 Microphotographs of investigated Zechstein salt rocks showing primary and deformation structures. a "Kristallbrocken" porphyroclasts (red arrows) and serrated grain boundaries of halite in Zechstein rock salt. b Intercrystalline (white arrows) and intracrystalline (red arrow) fluid inclusions in halite. c Subgrain free, angular halite grains invading a subgrain rich grain. Fluid inclusions are visible at grain boundaries (white arrows) as well as inside the angular shaped grain (red arrow). d Euhedral-to-subhedral anhydrite crystals located at fluid-rich halite grain boundary. e Large subhedral to microcrystalline clustered anhydrite crystals. f Cross-twinned polyhalite crystals with halite inclusions (see arrows) 

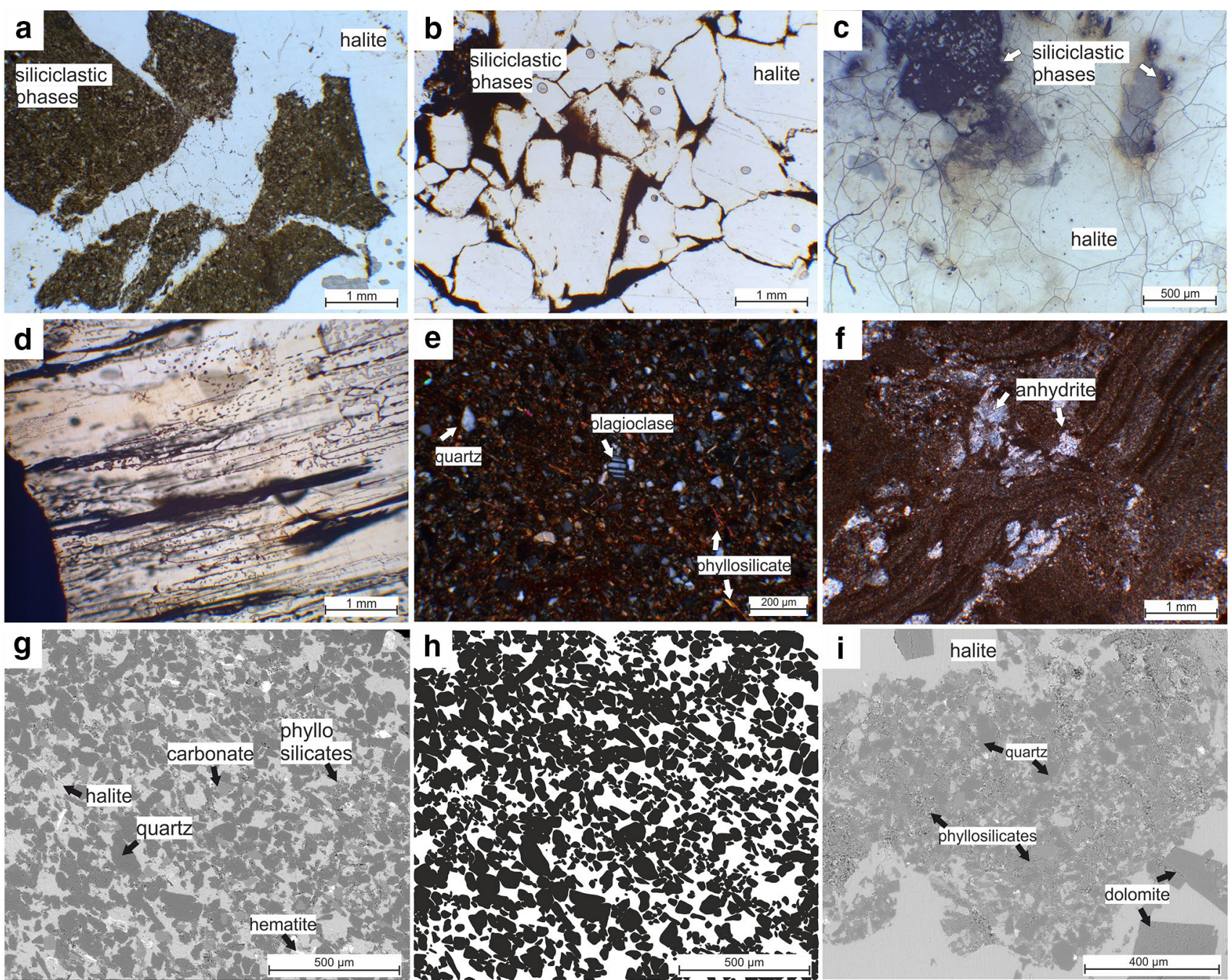

Fig. 4 Microphotographs of investigated Rotliegend salt rocks showing primary and deformation structures. a Rotliegend halite with disintegration of siliciclastic matrix by halite filled fractures characterized by smaller halite grain size. b Euhedral and subhedral to lobate halite grains surrounded by detrital material. c Subgrains in halite with various size around siliciclastic phases. d Fluid inclusions at grain boundaries of fibrous halite. e Equal distribution of detrital clasts inside the siliciclastic matrix with large plagioclase crystal

The siliciclastic matrix is dominated by silt-sized clasts up to $100 \mu \mathrm{m}$ in diameter. Single clasts usually show a subrounded-to-subangular shape (Fig. 4a). They comprise detrital clasts of quartz, K-feldspar, plagioclase, carbonate phases and phyllosilicates (Fig. 4e). Phyllosilicates have been shown to consist of white mica and chlorite (Henneberg et al. 2018). The reddish color is caused by evenly distributed ferrous phases of sub-micron size. Larger crystals of hematite, up to $20 \mu \mathrm{m}$ in diameter, are visible under the SEM (Fig. 4g).

Most of the detrital siliciclastic domains show large amounts of halite cement (Fig. 4g-i), while cements consisting of anhydrite and phyllosilicates occur locally. (center) and phyllosilicates under crossed polarizers. f Bedding and anhydrite nodules in siliciclastic domain under crossed polarizers. g Detrital phases with large grain size surrounded by halite cement (see also Henneberg et al. (2018)). h Outline of detrital phases yielding $36 \%$ of intergranular area. i Detrital phases comprising halite and phyllosilicate cement with large dolomite crystals located at phase boundaries

Quantification of the intergranular area based on SEM images (Fig. 4h), yielded an amount of $28 \%$ and $36 \%$ depending on the size of single detrital clasts. The high amount of cement implies low degrees of compaction with point contacts or absent contacts in between single clasts. Apart from preserved sedimentary layers, siliciclastic phases show a random orientation within halite cement. From microstructural observation, no evidence for local dissolution processes within the siliciclastic domains was found in the areas observed under the SEM. However, indicators for partial dissolution of carbonate phases such as indistinct grain-to-grain contacts and etched grain 
boundaries could be observed locally in carbonate-rich phases inside the siliciclastic domains (Fig. 5d).

Carbonate phases are randomly present as detrital components of the siliciclastic domains, while single crystals of euhedral dolomite, with grain sizes of up to $200 \mu \mathrm{m}$, can be observed locally at phase contacts between halite and siliciclastic matrix (Figs. 4i, 5b), and in a few cases as part of the siliciclastic domains (Fig. 5c, d).

\section{EBSD analysis}

EBSD maps of fibrous halite in high-strain domains (Fig. 6a, f) display a large variety in crystallographic orientation of the $\mathrm{mm}$ to $\mathrm{cm}$-sized crystals. Single halite fibers show a slight change in crystal orientation over the grain area, as is indicated by a color change in the EBSD map. This change in orientation points to a bending of the crystal lattice inside the halite fibers (Fig. 6b, g). Orientation plots indicate progressive rotation of the crystal lattice with the long axis of single halite fibers (Fig. 6d, e). Orientation plots of the single fibers do not reveal a crystallographic preferred orientation (CPO) (Fig. 6c, h).

In the vicinity of halite fibers, misorientation profiles show a wide range in the degree of misorientation detected over single (sub)grain boundaries ranging from $1^{\circ}$ to $35^{\circ}$. Changing misorientations over the lateral extent of single grain or subgrain boundaries could be detected (Fig. 7a). A large number of medium misorientations between $7^{\circ}$ and $15^{\circ}$ were detected (Fig. 7b). The resulting misorientations are in the transitional stage between grain and subgrain boundary based on the definition of high-angle (grain) boundaries having a misorientation of more than $10^{\circ}$ (Trimby et al. 2000). The presence of subgrain-sized grains in subgrainrich grains (see arrows in Fig. 7) indicate possible grain
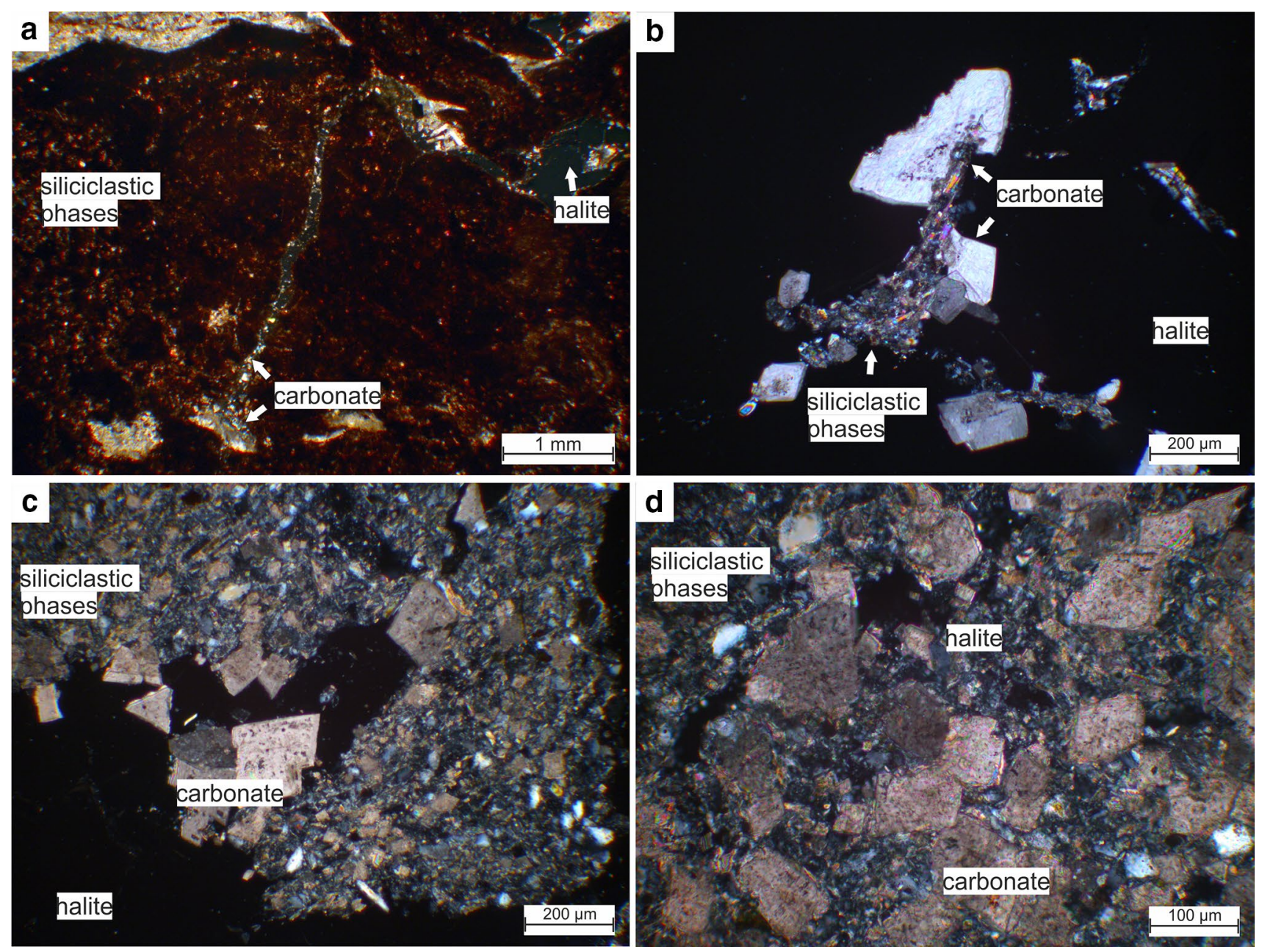

Fig. 5 Micrographs of carbonate phases of thick (a) and thin sections (b-d). a Close-up view of microfractures in detrital domains. Phase boundaries are decorated with tiny carbonate and anhydrite crystals. b Carbonate crystals growing at phase contacts of siliciclastic phases

to halite. c Carbonate-rich detrital domain with euhedral crystals located at phase boundaries to halite. d Carbonate within detrital domain with indistinct grain-to-grain contacts and partly etched grain boundaries 


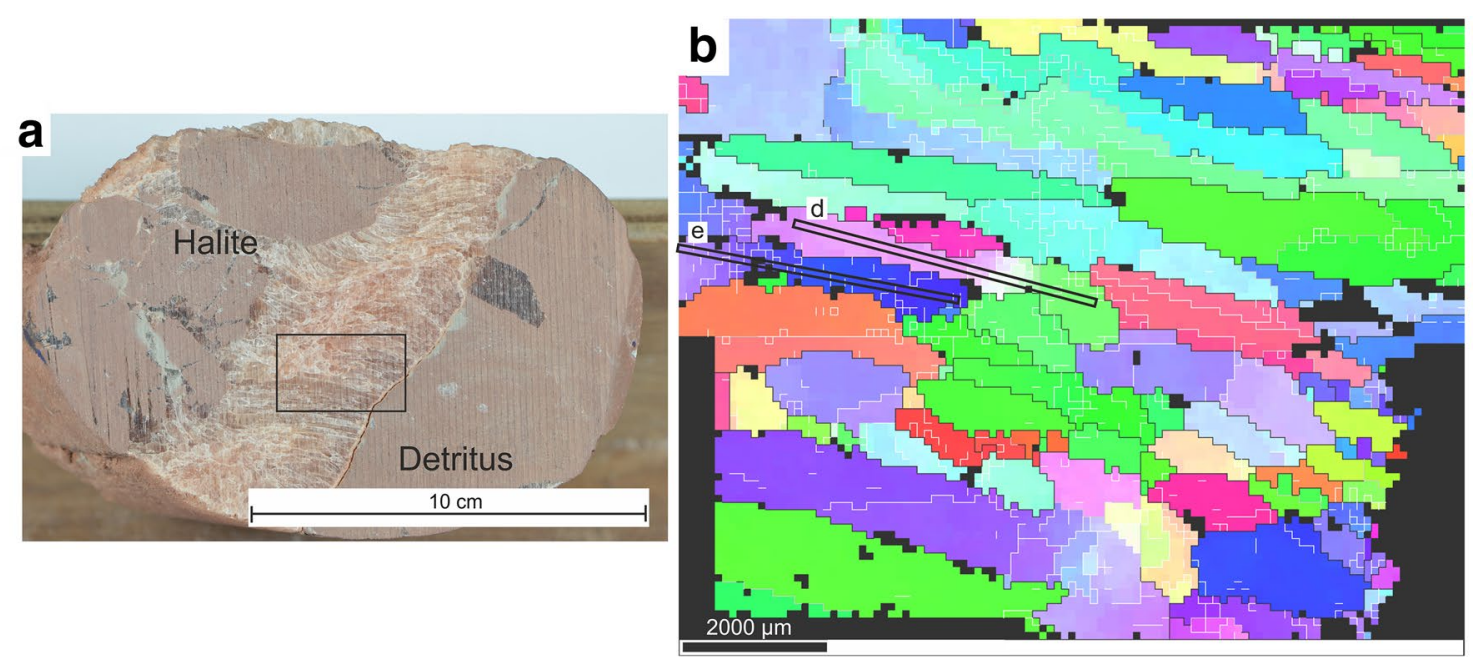

C
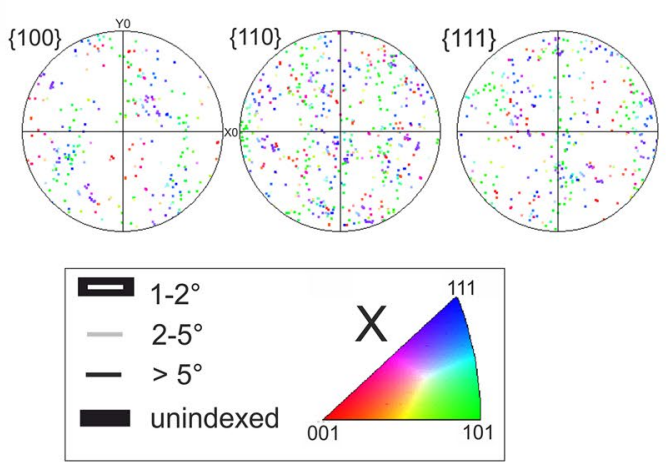

e

d
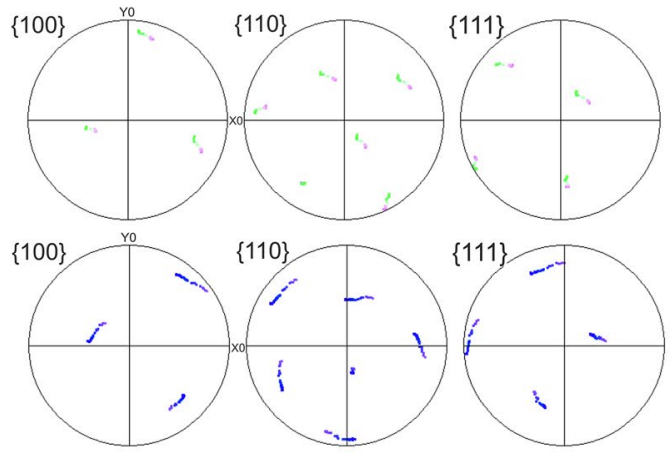

$\{111\}$

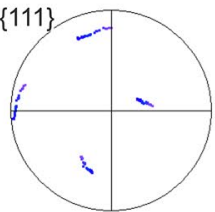

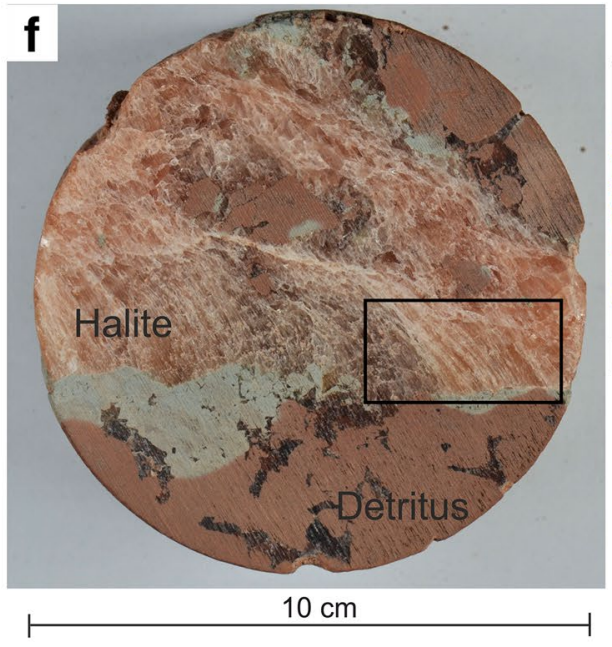

Fig. 6 Polished samples and EBSD data of Rotliegend halite obtained from high-strain domains. $X$ is horizontal, $Y$ is vertical. a Fibrous halite in a vein with fibers subperpendicular to the boundary wall rock/ vein (drill core cross cut perpendicular to the vein orientation). Partial sigmoidal shape of halite fibers indicates shear strain inside the vein. Box marks analyzed area. b EBSD map of fibrous halite. Boxes indicate subsets of orientation measurements in $\mathbf{d}$ and e. c Upper hemisphere equal-area stereographic projections showing orientation of major crystallographic directions within 95 spot measurements of

h
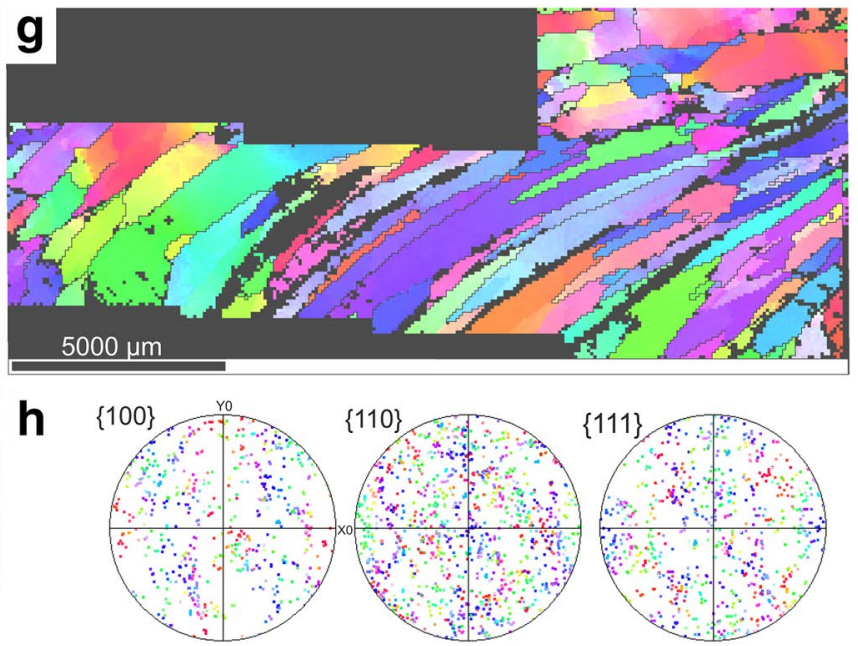

the EBSD map shown in $\mathbf{b}$; each point represents a single grain. $\mathbf{d}$, $\mathbf{e}$ Upper hemisphere equal area stereographic projections of the inserts shown in $b$ showing rotation of crystallographic directions over the measured areas. $\mathbf{f}$ Drill core cross cut with halite fibers showing a strong SPO. Box marks analyzed area. $\mathbf{g}$ EBSD map of halite fibers. $\mathbf{h}$ Upper hemisphere equal area stereographic projections showing orientation of major crystallographic directions within 197 point measurements of the EBSD map shown in $\mathbf{g}$; each point represents a single grain 

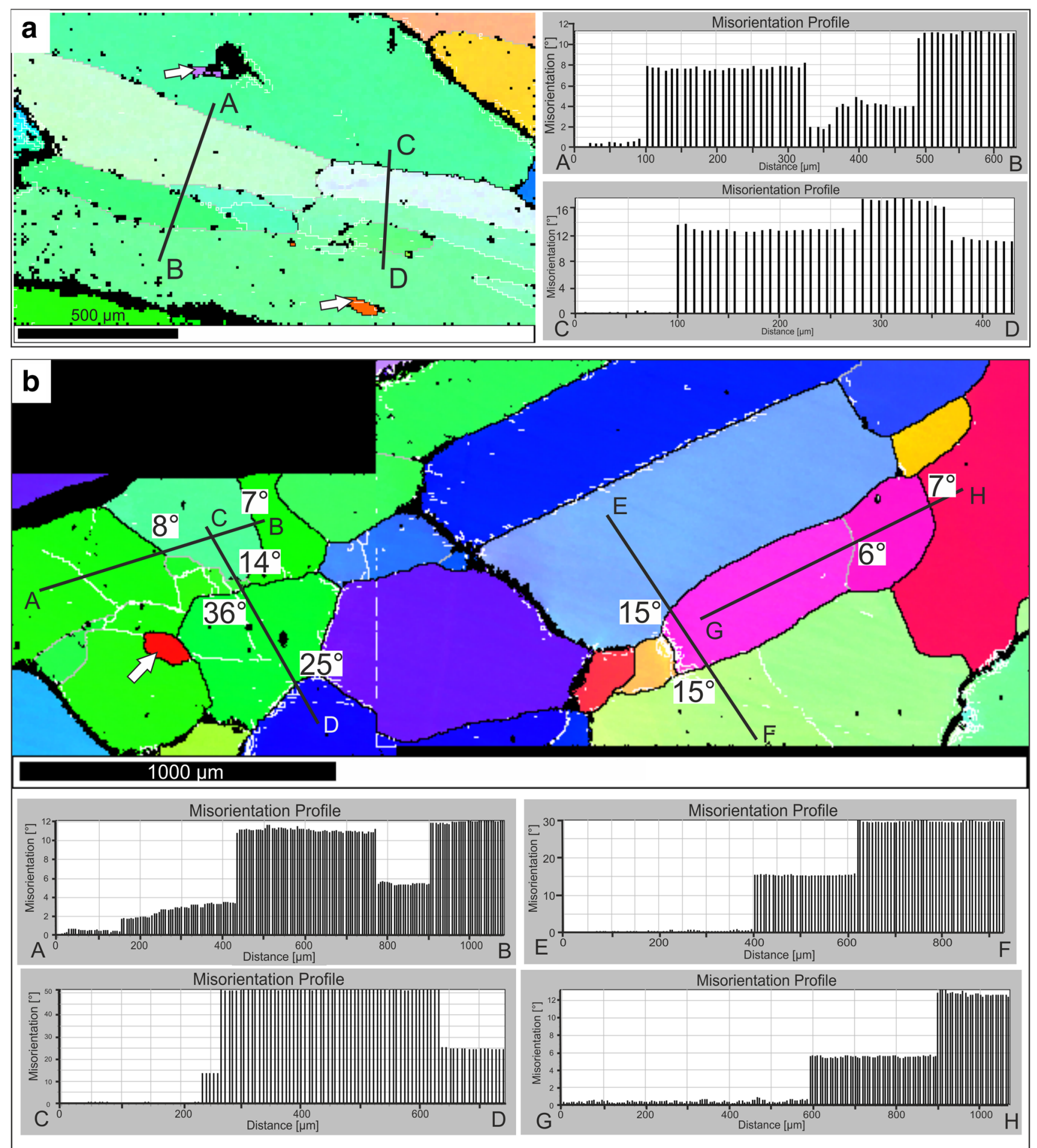

Fig. 7 Misorientations measured over grain and subgrain boundaries of Rotliegend halite. a EBSD map of elongated subgrains. Misorientation profiles indicate changing misorientation over single subgrain boundaries from $2^{\circ}$ to $14^{\circ}$, respectively. Sampled area is shown in

Fig. 6a. b EBSD map with misorientation profiles showing changing misorientation over single grain/subgrain boundaries from $6^{\circ}$ to $35^{\circ}$. Sampled area is shown in Fig. $6 f$ 
formation by progressive subgrain rotation (Bestmann and Prior 2003).

\section{Mineralogical composition and bromide concentration in halite}

According to the geochemical data, the Rotliegend bulk samples consist of varying amounts of halite, anhydrite and insoluble rock content (Fig. 8a, b). The anhydrite concentration accounts for max $5 \mathrm{wt} \%$. About half of the samples are anhydrite free. The content of insoluble phases is highly variable according to the irregular distribution of siliciclastic components in halite and accounts for ca. 1-56 wt \%. All samples collected from Rotliegend rock salt show bromide concentrations ranging from 3 to $62 \mu \mathrm{g} / \mathrm{g}_{\text {halite }}$, which points to a continental to recycled marine brine source for halite formation.

In Zechstein rock samples, the average amount of insoluble phases accounts for $1 \mathrm{wt} \%$ of the bulk composition, and anhydrite or polyhalite are the main secondary phases with maximum concentrations of $14 \mathrm{wt} \%$ anhydrite and $2 \mathrm{wt} \%$ polyhalite. Bromide concentrations in halite are significantly higher compared to the Rotliegend sequences covering an interval of $60-247 \mu \mathrm{g} / \mathrm{g}_{\text {halite }}$. Bromide concentrations of more than $157 \mu \mathrm{g} / \mathrm{g}_{\text {halite }}$ are restricted to polyhalite-bearing samples.

For the Rotliegend lithology, local sampling of single fabric types in eight polished core sections reveals a fabric related distribution of two domains of bromide concentrations in halite: average local bromide concentration in fibrous halite (24-62 $\mu \mathrm{g} / \mathrm{g}_{\text {halite }}$ ) exceeds the average local bromide concentrations from surrounding large halite crystals ( $3-34 \mu \mathrm{g} / \mathrm{g}_{\text {halite }}$ ). The trend can be found in samples from different depths with the mean bromide concentration changing slightly in between the two fabric types (Fig. 8c-e). Irregular distribution of bromide in halite with the fabric type suggests two different brine sources for fabric formation within this rock type and excludes the large adjacent halite crystals as a source for fibrous halite formation. Due to low bromide concentrations, a continental brine source is suggested for the formation of large halite crystals, while fibrous halite shows bromide concentrations typical for the first generation of halite that crystallized from seawater or from a recycled marine brine (Fisher and Hovorka 1987; Hardie 1984; Herrmann et al. 1973).

\section{$\mathrm{U}-\mathrm{Pb}$ dating of carbonate phases}

$\mathrm{U}-\mathrm{Pb}$ isotope analyses were performed on three different samples with two results being obtained from the same sample mounts analyzed on two different days. Measurements were performed on two samples (17Ki13 and 16Ki12), where euhedral shape and location of carbonate crystals at phase boundaries of halite and siliciclastic domains indicate authigenic carbonate formation due to secondary processes (Fig. 5b, c). Especially in sample 17Ki13, partial dissolution of diagenetic carbonate phases is observed inside the siliciclastic domains (Fig. 5d). Measurements yielded lower intercept ages at $124 \pm 27 \mathrm{Ma}$ and $177 \pm 21 \mathrm{Ma}$ (17Ki13) as well as $158 \pm 45 \mathrm{Ma}$ and $167 \pm 28 \mathrm{Ma}$ (16Ki12) (Fig. 9a-f).

Elevated mean square weighted deviation (MSWD) of 2.5 to 6.9 on five of the regression lines indicate some scatter of the data. This possibly reflects the sampling of carbonate domains crystallized at different times. This could be heterogeneous domains e.g., due to partial recrystallization of an earlier carbonate phase (Fig. 9b, c). Combined with the limited spread in the ${ }^{238} \mathrm{U} /{ }^{206} \mathrm{~Pb}$ ratio this resulted in relative large uncertainties on the obtained ages.

The two measurements in sample 16Ki12 cover an age interval from 113 to $203 \mathrm{Ma}$ and thus reflect a Jurassic to lower Cretaceous age of crystallization. A similar age span is covered by the measurements performed on sample 17Ki13 (97-198 Ma) but without overlap of the two separate measurements.

Measurements in sample 17Ki30 included small carbonate crystals as fracture infill in detrital domains along with fibrous halite (Fig. 9g). However, the results show large uncertainties and differ significantly with one measurement yielding Triassic to middle Jurassic age (191 $\pm 33 \mathrm{Ma})$, and the other measurement yielding late Carboniferous to early Triassic age (284 $\pm 42 \mathrm{Ma})$ (Fig. 9h, i).

\section{Discussion}

\section{Halite formation and origin of fabric}

Rotliegend rock salt is interpreted to preserve displacive evaporites of playa deposits characterized by coarse halite crystals with euhedral-to-anhedral outlines without preserved sedimentary bedding (Casas and Lowenstein 1989; Rosen 1994). According to this view, halite formed as early diagenetic precipitate in the sediment due to capillary evaporation (Handford 1982; Hovorka 1987; Warren 2016). The obtained range of bromide concentrations in Rotliegend rock salt, ranging from 3 to $62 \mu \mathrm{g} / \mathrm{g}_{\text {halite }}$ is not in line with previous investigations which yielded bromide concentrations $<20 \mu \mathrm{g} / \mathrm{g}_{\text {halite }}$ from Rotliegend halite of the Central Glückstadt Graben (Holser 1979) and of the Northeast German Basin (Katzung 1991). Low bromide concentrations between 3 and $34 \mu \mathrm{g} / \mathrm{g}_{\text {halite }}$ associated with secondary formed large halite crystals point out that continental groundwater served as the main source for halite formation. A restricted activity of reducing fluids in the otherwise oxidizing environment can be deduced from local bleaching. Large amounts of halite cement and the random orientation of detritus observed in the siliciclastic 

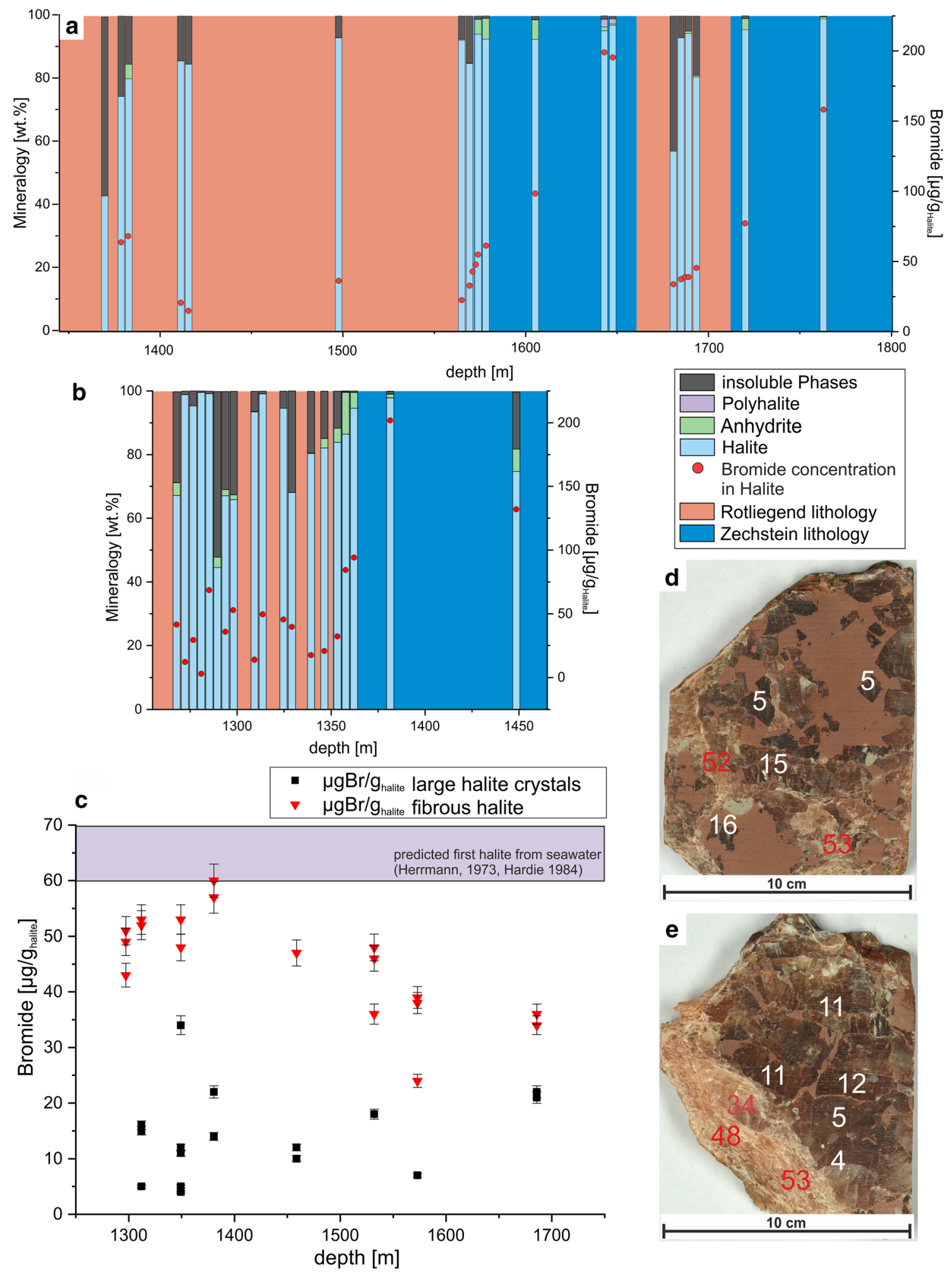

Fig. 8 a, b Mineralogical composition and bromide concentration in halite of bulk samples of Rotliegend and Zechstein rock salt over sampled depths in two different drill cores. Bars do not represent true depths, but were slightly shifted to avoid overlaps. c Local changes in bromide concentration with the fabric type over sampled depth intervals in Rotliegend halite. $\mathbf{d}$, e Sampled areas of $\mathbf{c}$ with according bromide concentration in large halite crystals (white numbers) and fibrous halite (red numbers) 

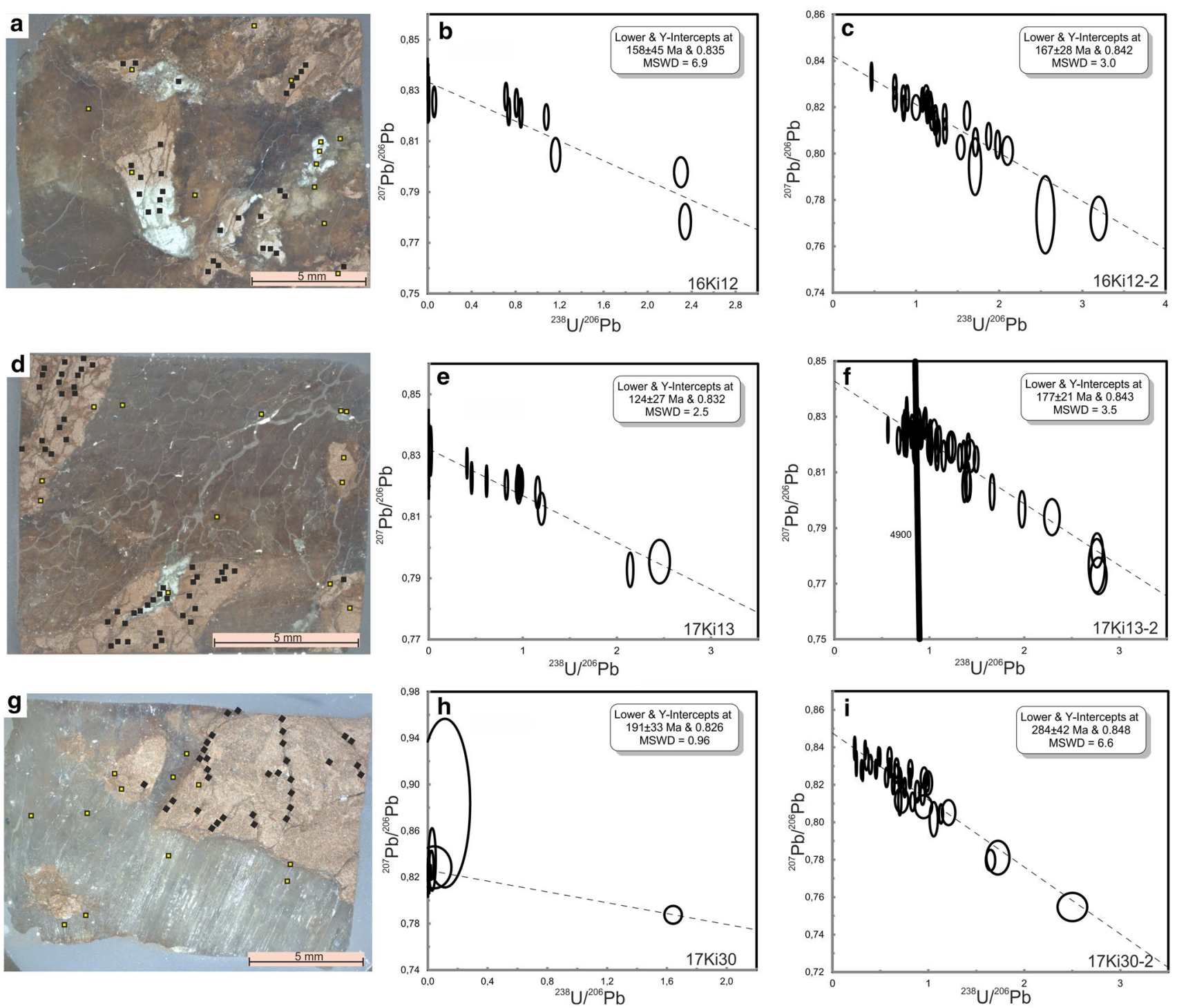

Fig. 9 Macroscopic view of sample plugs and Tera-Wasserburg diagrams of $\mathrm{U}-\mathrm{Pb}$ isotope data of carbonate phases from three samples. Data-point error ellipses are $2 \sigma$. Lower intercept ages should correspond to the time of crystallization. a Sample 16 Ki12 with ablated spots located at siliciclastic domains (yellow: results in b, black: results in $\mathbf{c})$. b, $\mathbf{c}$ Results of ablated spots of sample $16 \mathrm{Ki} 12$ yield the same age within errors. d sample $17 \mathrm{Ki} 13$ with sample spots located

domains suggest complete early diagenetic cementation prior to compaction. The lack of evaporitic mineral phases other than halite and minor anhydrite reveals salt formation by low to moderate evaporation grades without contribution of elevated ion concentrations of $\mathrm{K}$ or $\mathrm{Mg}$. Indicators for later deformation affecting the shape of displacive halite and mineral replacement due to burial and mudrock compaction as described by Leitner et al. (2013) were not found. Preservation of this fabric type was possible because the incompetent salt was shielded by the surrounding competent siliciclastic material. in siliciclastic domains or at the contact to halite (yellow: results in $\mathbf{e}$, black: results in f). e, f Results of ablated spots in $17 \mathrm{Ki} 13$ yield different ages with an offset of $53 \mathrm{Ma}$ and no overlap of the error bars. g Sample 17Ki30 with ablated spots located at halite filled microfractures in siliciclastic domain adjacent to halite fibers (yellow: results in $\mathbf{h}$, black: results in i). h, i Sample 17Ki30 yields different ages with an overlap of $93 \mathrm{Ma}$ and no overlap of the error bars

Zechstein halite formed as part of the marine Permian Zechstein group as is indicated by higher bromide concentrations in halite and minor concentrations of anhydrite and polyhalite. The interval of bromide concentration and the observed main mineral phases fit well with previous investigations of diapiric Staßfurt Main Salt (z2HS) from the North German Basin (Bornemann et al. 2008; Küster et al. 2009). The dominance of polyhalite over anhydrite in some samples is related to higher bromide concentrations. The presence of "Kristallbrocken" porphyroclasts, on the other hand, is an indicator for the partial preservation of primary fabrics. 
The brecciation of the porphyroclasts is related to the competence contrast to the surrounding halite matrix as inferred by Küster et al. (2010).

\section{Rock salt deformation}

Microstructural analysis allows the identification of several deformation and recovery mechanisms that have acted on the salt during diapir formation.

Rock salt of both Rotliegend and Zechstein successions has been deformed by dislocation creep, which is indicated by subgrains in all types of halite. The low differential stresses (Henneberg et al. 2018), calculated with the subgrain size piezometer, fit well with the observations reported previously from diapiric rock salt (Mertineit et al. 2014; Schléder 2006; Thiemeyer et al. 2016). However, a variation in subgrain formation as a result of the accommodation of high strain that is deduced from the structural setting and rock salt macrofabric cannot be concluded.

The dominance of euhedral halite crystals, which invaded subgrain-rich halite grains in Zechstein rock salt suggests fluid assisted grain boundary migration (GBM) with consecutive replacement of subgrain-rich grains as a main recovery mechanism. The replacement process of pre-existing, dislocation-rich halite grains via GBM has been reported to act in natural rock salt through numerous examples (Leitner et al. 2011; Schléder and Urai 2005; Thiemeyer et al. 2016; Urai and Spiers 2007). However, in the studied sections, evidence for GBM to operate in halite is only preserved in the Zechstein rocks. It is implied that this is due to the high amount of available grain boundary fluids found in Zechstein rock salt, which supports the weakening of the mechanical strength of rock salt (Peach et al. 2001; Pennock et al. 2006; Ter Heege et al. 2005; Urai et al. 1987, 1986). The preservation of inclusion rich "Kristallbrocken" halite porphyroclasts points out that recovery is restricted to areas with enhanced interfacial free energy (small grain size) and did not lead to recrystallization of the entire halite fabric.

EBSD measurements indicate crystal plastic deformation having acted in areas of inferred high strain in the Rotliegend halite. Progressive lattice rotation with the long axis of halite fibers can be interpreted as subboundary migration (Drury and Urai 1990). Changing degrees of misorientation over the propagation of subgrain boundaries show progressive rotation. This is in contrast to most observations in naturally deformed halite with only small misorientations detected over single subgrain boundaries (Kneuker et al. 2014; Linckens et al. 2016; Thiemeyer et al. 2016). Recrystallization by subgrain rotation (SGR) with the formation of new grains is indicated locally by both subgrain misorientation exceeding $10^{\circ}$ and the presence of smaller distinct grains that match the size of subgrains (Fig. 6).
Two different recovery mechanisms were active in the analyzed rocks: GBM is dominant in Zechstein halite with high amounts of fluids, while local SGR is inferred in areas of high strain in the Rotliegend strata, where less fluid inclusions are observed in halite. Recovery compromised the buildup of intracrystalline deformation by dislocation creep. For this reason, evidence for high strain in halite that was largely accommodated by the formation of subgrains, as shown from deformation experiments (Linckens et al. 2016), is lacking in the studied rocks.

The presence of insoluble phases in Rotliegend rock salt addresses the importance of pressure solution in this rock type, which will be discussed in the following sections. Secondary phases are believed to increase the strain rate during pressure solution due to the increased amount of phase contacts (Hickman and Evans 1995; Renard et al. 2001; Zubtsov et al. 2004). Based on deformation patterns and microstructures of naturally deformed impure rock salt in high strain domains, Leitner et al. (2011) and Závada et al. (2015) inferred enhanced ductility of impure rock salt due to increased diffusion rates along phase contacts and implied decoupling of salt types of different composition according to rheological contrasts.

\section{Formation of fibrous halite}

The presence of siliciclastic components and halite results in stress and strain peaks in parts of the studied rock (Henneberg et al. 2018) with concurrent conservation of primary subhedral halite. Subsequent to the formation of large halite crystals from continental brines, fibrous halite was formed from a different genetic source as is indicated by higher bromide concentrations in this type of halite.

The formation of fibrous halite is related to deformation in form of fractures straddling the detrital domains. The fractures were filled with brine, from which the halite fibers precipitated. Formation of extension fractures in the siliciclastic domains require low differential and low effective stresses. Low effective stresses at deeper structural levels are significantly promoted by elevated fluid pressure (Hubbert and Rubey 1959; Secor 1965). Since diapiric rise of salt rocks is expected to result in crystal plastic deformation of the incompetent rock salt matrix, disintegration of siliciclastic domains was possible by elevated fluid pressure and hydrofracturing. Fluid overpressure could be generated by two different mechanisms:

1. Entrapment of fluids of early diagenetic origin due to local undercompaction of the sediment. Overpressure could occur spontaneously with increasing fluid pressure by significant reduction of effective stresses even at high confining pressures at local changes in differential load. Local undercompaction in detrital domains is 
likely due to large detected amounts of halite cements and the generally high cementation rate in saline pans, where complete cementation is reached at burial depths of $45 \mathrm{~m}$ (Casas and Lowenstein 1989).

2. Release of fluids during burial and diagenetic mineral transformation with rising temperature and pressure. Burial temperatures at the Zechstein base within adjacent areas were modeled to have reached $100{ }^{\circ} \mathrm{C}$ at the end of the Triassic (Rodon and Littke 2005) and thus were sufficient to generate fluids from e.g., the transformation of smectite to illite (Bruce 1984; Freed and Peacor 1989). Fluids were contained inside the formation due to the sealing Rotliegend and Zechstein rock salt sequence in the overburden.

Fibrous halite in open pore space is attributed to precipitation from brine, which could result from pressure solution in high-stress domains along the contacts between halite and competent silicate components. This is supported by the absence of a CPO in fibrous halite as detected from orientation measurements. One possible explanation for systematically higher bromide concentrations in fibrous halite is concentration of bromide in interstitial brines or by sorption onto detrital minerals during sediment formation. Bromide can absorb onto amorphous Fe-oxide and clay minerals at low pH values (Goldberg and Kabengi 2010). High bromide concentrations in halite associated with mudstone were previously described by Fisher and Hovorka (1987).

Evidence for a contribution of Zechstein fluids to the development of Rotliegend fibrous halite like precipitation of $\mathrm{K}-\mathrm{Mg}$ phases, dissolution features and preserved amounts of fluid phases along halite grain boundaries is absent. Contribution of Zechstein fluids to the formation of fibrous halite in Rotliegend rock salt would require a mixture of Rotliegend and Zechstein fluids, since hypothetical Zechstein fluids would be expected to exceed bromide concentrations of Zechstein salt (Braitsch and Herrmann 1963; Herrmann et al. 1973; Siemann and Schramm 2000).

The combination of geochemical and microstructural evidence gives rise to the assumption that fibrous halite has been formed due to pressure solution, possibly by crystallization due to dilatancy at elevated fluid pressures, but has been deformed by dislocation creep and local subgrain rotation recrystallization during a later deformation event.

\section{Timing of deformation and fabric formation}

The oldest age obtained by $\mathrm{U}-\mathrm{Pb}$ dating of calcite $(284 \pm 42 \mathrm{Ma})$ reflects the age of sedimentation or diagenesis of the rock, referring to fracture formation in the detrital domains. The other ages are significantly younger ranging from late Triassic to late Cretaceous when taking the uncertainties of ages into account. However, most of these ages are straddling the Jurassic period (Fig. 10). All measurements of sample $16 \mathrm{Ki} 12$ and $17 \mathrm{Ki} 13$ refer to carbonate phases of secondary origin inside and around detrital domains. Measurements of 16Ki12 with an overlapping age span can be related to the same deformation event. However, the spread in ${ }^{238} \mathrm{U} /{ }^{206} \mathrm{~Pb}$ ratios resulting in a large MSWD could point out multiphase deformation within a tight age span in the measured rock section covering two single events of a similar (Jurassic) age. In contrast, the obtained results from sample 17Ki13 cover two age spans without overlap of the two different measurements. The difference is not reflected by measurement of different carbonate microfabrics in the section, however, the carbonate microstructure within this sample shows evidence for dissolution of secondary carbonate (Fig. 5d). The data thus point out two deformation events related to different age spans within one studied rock section, one spanning the Jurassic period and the other ranging from Late Jurassic to Upper Cretaceous. In total, four of the obtained six measurements can be related to the main structural growth of the Kiel-Honigsee structure after Warsitzka et al. (2016) (Fig. 10). Enhanced diapirism during that time is related to basin differentiation within the NGB (Brink et al. 1992; Kockel 2002; Kley et al. 2008) and to extension-related regional stresses leading to formation of marginal troughs and acceleration of late Triassic induced reactive diapirism within salt walls of the marginal Glückstadt Graben (Maystrenko et al. 2006).

According to $\mathrm{U}-\mathrm{Pb}$ dating and existence of fibrous halite, there is multiple evidence for fluid enhanced crystallization of mineral phases: $\mathrm{U}-\mathrm{Pb}$ analyses point out Permo-Triassic halite formation to burial ages for carbonate in halite filled fractures (sample 17Ki30) and thus relate hydrofracturing to fluid overpressure of entrapped interstitial fluids. The calculated lower to middle Jurassic ages indicate syntectonic reorganization in parts of the fabric inside the detrital domains including mineralization of carbonate phases. During this time interval, fluid mobility and resulting mineralization as a result of basin differentiation has had an impact on Permian deposits within different parts of the NGB (e.g., Gaupp et al. 1993; Nadoll et al. 2019; Schmidt Mumm and Wolfgramm 2004; Wüstefeld et al. 2017). Regarding the different age spans of sample $17 \mathrm{Ki} 13$ covering the same rock fabric, a first phase of fabric formation during early to middle Jurassic can be assumed, followed by reactivation during Cretaceous, prior to, or at the beginning of the second phase of salt structure growth (Fig. 10). It can therefore be deduced that fabric formation due to fluid overpressure was a dynamic process that was locally active throughout diapiric ascent depending on local evolution of the stress field. This mechanism could have significantly contributed to the overall mobility of the halitic Rotliegend sequence and therefore provides an explanation for implementation of the rock sequence into the process of diapirism. 


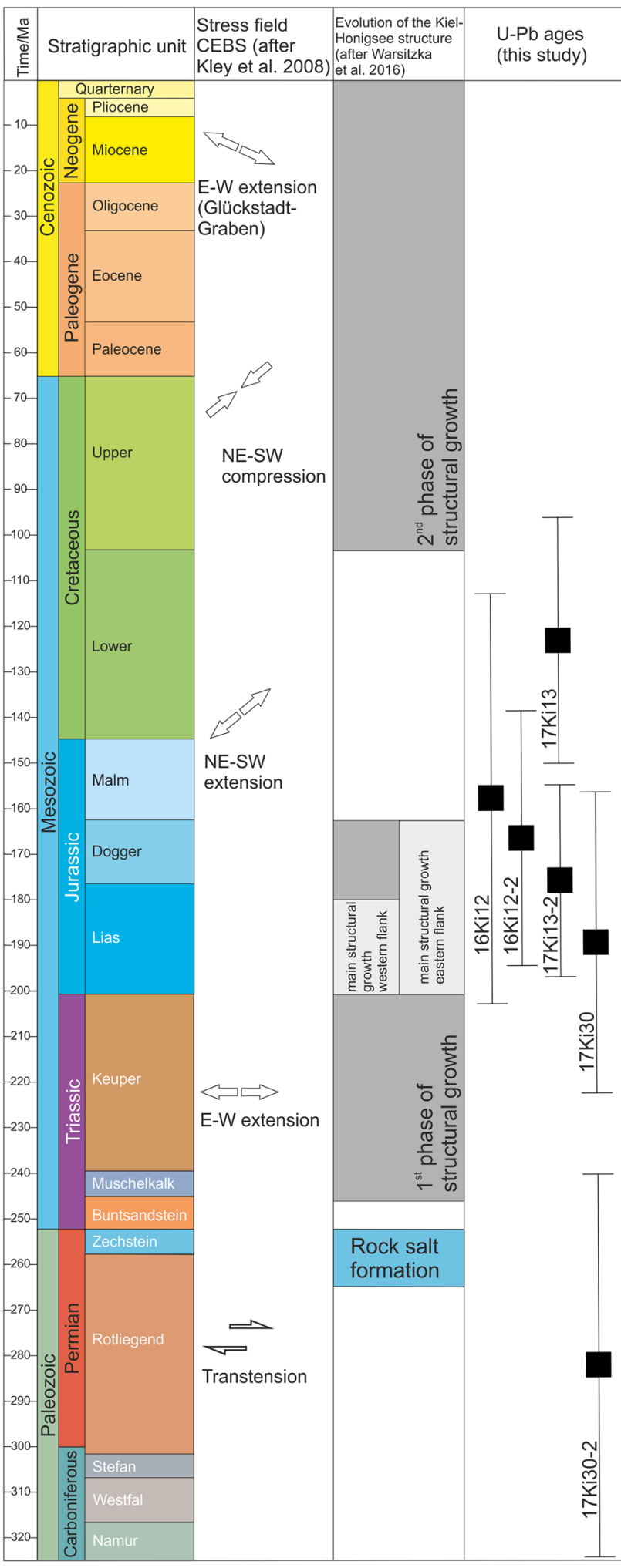

Fig. 10 Stratigraphy of the NGB together with stress field evolution in comparison to the evolution of the structural evolution of the KielHonigsee structure (after Kley et al. (2008); Warsitzka et al. (2016)) and $\mathrm{U}-\mathrm{Pb}$ ages (this study)

\section{Conclusions}

The new results presented above pinpoint multiple indicators for a multistage evolution of diapiric rock salt. The following conclusions can be drawn:

- Sedimentary and early diagenetic fabrics are preserved in parts of the rock salt fabric in Rotliegend and Zechstein rock salt, which is possible due to strain concentration in halite during deformation.

- Evolution of rock salt fabric in siliciclastic rich Rotliegend rock salt was significantly influenced by hydrofracturing and local pressure solution followed by fibrous halite formation as a dynamic process.

- Local fluid and phase distribution influences the activity of different fluid enhanced processes: GBM as a recovery mechanism in fluid-rich Zechstein halite and hydrofracturing in detrital domains of dry Rotliegend halite as a result of initial fluid overpressure.

- Crystal plastic deformation via dislocation creep represents the last retraceable stage of fabric evolution. Additional recovery by SGR was active in areas of local high strain.

- U-Pb dating traces both early-stage fracture formation related to salt rock formation and multiphase syntectonic fabric reorganization that can be correlated with Jurassic to Cretaceous stages of diapir formation.

Acknowledgements Open Access funding provided by Projekt DEAL. We kindly thank Stadtwerke Kiel for providing sample material, R. Götze, T. Faust and M. Gern for sample preparation at BGR Hannover and R. Bergmann, L. Linnenschmidt and A. Degtjarev for ICPOES measurement, also at BGR Hannover. The work was supported by the Federal Ministry of Economics and Energy (03ET6062B and 9Y3215020000). This is FIERCE contribution 41.

Open Access This article is licensed under a Creative Commons Attribution 4.0 International License, which permits use, sharing, adaptation, distribution and reproduction in any medium or format, as long as you give appropriate credit to the original author(s) and the source, provide a link to the Creative Commons licence, and indicate if changes were made. The images or other third party material in this article are included in the article's Creative Commons licence, unless indicated otherwise in a credit line to the material. If material is not included in the article's Creative Commons licence and your intended use is not permitted by statutory regulation or exceeds the permitted use, you will need to obtain permission directly from the copyright holder. To view a copy of this licence, visit http://creativecommons.org/licenses/by/4.0/.

\section{References}

Bachmann GH, Voigt T, Bayer U, von Eynatten H, Legler B, Littke R (2008) Depositional history and sedimentary cycles in the 
Central European Basin System. In: Littke R, Bayer U, Gajewski D, Nelskamp S (eds) Dynamics of complex intracontinental basins. The Central European basin system. Springer, Heidelberg, pp 181-210

Baldschuhn R, Binot F, Fleig S, Kockel F (2001) Geotektonischer Atlas von Nordwest-Deutschland und dem deutschen NordseeSektor. Strukturen, Strukturentwicklung, Paläogeographie Geol $\mathrm{Jb}$ A 153

Best G (1989) Die Grenze Zechstein/Buntsandstein in Nordwest-Deutschland nach Bohrlochmessungen. Zeitschrift der Deutschen Geologischen Gesellschaft 140:73-85

Bestmann M, Prior DJ (2003) Intragranular dynamic recrystallization in naturally deformed calcite marble: diffusion accommodated grain boundary sliding as a result of subgrain rotation recrystallization. J Struct Geol 25:1597-1613

Borchert H, Muir RO (1964) Salt deposits. The origin, metamorphism and deformation of evaporites. D. van Nostrand Company Ltd, London

Bornemann O et al (2008) Standortbeschreibung Gorleben-Teil 3. Ergebnisse der über- und untertägigen Erkundung des Salinars. Geologisches Jahrbuch C 73

Braitsch O, Herrmann AG (1963) Zur Geochemie des Broms in salinaren Sedimenten: Teil I: Experimentelle Bestimmung der $\mathrm{Br}-V e r t e i l u n g$ in verschiedenen natürlichen. Salzsystemen Geochimica et Cosmochimica Acta 27:361-391

Brink H, Dürschner H, Trappe H (1992) Some aspects of the late and post-Variscan development of the Northwestern German Basin. Tectonophysics 207:65-95

Bruce CH (1984) Smectite dehydration-its relation to structural development and hydrocarbon accumulation in northern Gulf of Mexico basin. AAPG Bull 68:673-683

Casas E, Lowenstein TK (1989) Diagenesis of saline pan halite: comparison of petrographic features of modern, quaternary and Permian halites. J Sediment Petrol 59:724-739

Drury M, Urai J (1990) Deformation-related recrystallization processes. Tectonophysics 172:235-253

Fisher RS, Hovorka SD (1987) Relations between bromide content and depositional processes in bedded halite, Permian San Andres Formation, Palo Duro Basin, Texas. Carbonates Evaporites 2:67-82

Freed RL, Peacor D (1989) Variability in temperature of the smectite/ illite reaction in Gulf Coast sediments. Clay Miner 24:171-180

Gast R et al (2010) Rotliegend. In: Dornenbaal JC, Stevenson AG (eds) Petroleum geological atlas of the Southern Permian Basin Area. EAGE Publications, Houten, pp 101-121

Gaupp R, Matter A, Platt J, Ramseyer K, Walzebuck J (1993) Diagenesis and fluid evolution of deeply buried Permian (Rotliegende) gas reservoirs, northwest Germany. AAPG Bull 77:1111-1128

Gaupp R, Gast R, Forster C (2000) Late Permian playa lake deposits of the Southern Permian Basin (Central Europe). In: GierlowskiKordesch EH, Kelts KR (eds) Lake basins through space and time: AAPG studies in Geology, 46th edn. American Association of Petroleum Geologists, Washington, pp 75-86

Geluk MC (2005) Stratigraphy and tectonics of Permo-Triassic basins in the Netherlands and surrounding areas. Dissertation, Utrecht University

Gerdes A, Zeh A (2006) Combined U-Pb and Hf isotope LA-(MC-) ICP-MS analyses of detrital zircons: comparison with SHRIMP and new constraints for the provenance and age of an Armorican metasediment in Central Germany. Earth Planet Sci Lett 249:47-61

Gerdes A, Zeh A (2009) Zircon formation versus zircon alterationnew insights from combined $\mathrm{U}-\mathrm{Pb}$ and $\mathrm{Lu}-\mathrm{Hf}$ in-situ LA-ICPMS analyses, and consequences for the interpretation of Archean zircon from the Central Zone of the Limpopo Belt. Chem Geol 261:230-243
Goldberg S, Kabengi N (2010) Bromide adsorption by reference minerals and soils. Vadose Zone J 9:780-786

Handford CR (1982) Terrigenous clastic and evaporite sedimentation in a recent continental-sabkha playa basin, Bristol Dry Lake, California. In: Handford CR, Loucks RG, Davies GR (eds) Depositional and diagenetic spectra of evaporites-a core workshop, 3rd edn. SEPM Core Workshop, Tulsa, pp 65-74

Hardie LA (1984) Evaporites; marine or non-marine? Am J Sci 284:193-240

Henneberg M, Mertineit M, Hammer J, Zulauf G (2018) Fabric, paleostress and mineralogical composition of impure Rotliegend rock salt (North German Basin). In: Fahland S, Hammer J, Hansen F, Heusermann S, Lux K-H, Minkley W (eds) Proceedings of the 9th Conference on the Mechanical Behavior of Salt (SaltMech IX), Hannover, pp 131-1421

Herrmann A, Knake D, Schneider J, Peters H (1973) Geochemistry of modern seawater and brines from salt pans: main components and bromine distribution. Contrib Miner Petrol 40:1-24

Hese F, Lademann K, Offermann P, Schaller A, Thomsen C (2016) Geological models as a tool for the planning of deep geothermal projects. In: Wuttke F, Bauer S, Sanchez M (eds) Energy geotechnics. Proceedings of the 1st international conference on energy geotechnics. Taylor \& Francis Group, London, pp 149-153

Hickman SH, Evans B (1995) Kinetics of pressure solution at halitesilica interfaces and intergranular clay films. J Geophys Res Solid Earth 100:13113-13132

Holser WT (1979) Rotliegend evaporites, Lower Permian of Northwestern Europe-geochemical confirmation of the non-marine origin. Erdöl und Kohle Erdgas Petrochemie 33:159-162

Hovorka S (1987) Depositional environments of marine-dominated bedded halite, Permian San Andres Formation, Texas. Sedimentology 34:1029-1054

Hubbert MK, Rubey WW (1959) Role of fluid pressure in mechanics of overthrust faulting. GSA Bull 70:115-206

Hudec MR, Jackson MPA (2007) Terra infirma: understanding salt tectonics. Earth Sci Rev 82:1-28

Hunsche U (2003) Thermomechanisches Verhalten von Salzgestein. Bundesanstalt für Geowissenschaften und Rohstoffe, Hannover

Jordan P (1987) The deformational behaviour of bimineralic limestonehalite aggregates. Tectonophysics 135:185-197

Katzung G (1991) Zu Auftreten, Ausbildung und Genese des Salinars in der mitteleuropäischen Saxon II-Senke (Oberperm). Zentralblatt für Geologie und Paläontologie 11:1565-1585

Kley J et al (2008) Strain and stress. In: Littke R, Bayer U, Gajewski D, Nelskamp S (eds) Dynamics of complex intracontinental basins: the Central European Basin System. Springer, Berlin, pp 97-124

Kneuker T, Zulauf G, Mertineit M, Behlau J, Hammer J (2014) The impact of finite strain on deformation mechanisms of Permian Stassfurt rock salt at the Morsleben site (Germany): constraints from microfabric studies and EBSD analyses. Zeitschrift der Deutschen Gesellschaft für Geowissenschaften 165:91-106

Kockel F (2002) Rifting processes in NW-Germany and the German North Sea Sector. Geol Mijnbouw 81:149-158

Küster Y, Schramm M, Bornemann O, Leiss B (2009) Bromide distribution characteristics of different Zechstein 2 rock salt sequences of the Southern Permian Basin: a comparison between bedded and domal salts. Sedimentology 56:1368-1391

Küster Y, Leiss B, Schramm M (2010) Structural characteristics of the halite fabric type 'Kristallbrocken' from the Zechstein Basin with regard to its development. Int J Earth Sci 99:505-526

Legler B, Gebhardt U, Schneider JW (2005) Late Permian non-marinemarine transitional profiles in the central Southern Permian Basin, northern Germany. Int J Earth Sci 94:851-862

Leitner C, Neubauer F, Urai JL, Schoenherr J (2011) Structure and evolution of a rocksalt-mudrock-tectonite: the haselgebirge in the 
Northern Calcareous Alps. J Struct Geol 33:970-984. https://doi. org/10.1016/j.jsg.2011.02.008

Leitner C, Neubauer F, Marschallinger R, Genser J, Bernroider M (2013) Origin of deformed halite hopper crystals, pseudomorphic anhydrite cubes and polyhalite in Alpine evaporites (Austria, Germany). Int J Earth Sci 102:813-829

Linckens J, Zulauf G, Hammer J (2016) Experimental deformation of coarse-grained rock salt to high strain. J Geophys Res Solid Earth 121:6150-6171

Maystrenko Y, Bayer U, Scheck-Wenderoth M (2005a) The Glueckstadt Graben, a sedimentary record between the North and Baltic Sea in north Central Europe. Tectonophysics 397:113-126. https://doi. org/10.1016/j.tecto.2004.10.004

Maystrenko Y, Bayer U, Scheck-Wenderoth M (2005b) Structure and evolution of the Glueckstadt Graben due to salt movements. Int J Earth Sci 94:799-814. https://doi.org/10.1007/s00531-005-0003-4

Maystrenko Y, Bayer U, Scheck-Wenderoth M (2006) 3D reconstruction of salt movements within the deepest post-Permian structure of the Central European Basin System - the Glueckstadt Graben. Neth J Geosci - Geol Mijnbouw 85(3):181-196

Maystrenko Y, Bayer U, Scheck-Wenderoth M (2016) 3D reconstruction of salt movements within the deepest post-Permian structure of the Central European Basin System - the Glueckstadt Graben. Neth J Geosci 85:181-196. https://doi.org/10.1017/s001677460 0021466

Maystrenko Y, Bayer U, Scheck-Wenderoth M (2017) Structure and evolution of the Glueckstadt Graben in relation to the other postPermian sub-basins of the Central European Basin System. In: Soto JI, Flinch J, Tari G (eds) Permo-Triassic salt provinces of Europe, North Africa and the Atlantic Margins. Elsevier, Amsterdam, pp 203-223

McCann T et al (2008) Permian. In: McCann T (ed) The geology of Central Europe: Precambrian and Palaeozoic, 1st edn. Geological Society of London, London, pp 531-597

Mertineit M, Schramm M, Hammer J, Zulauf G (2014) Deformation of anhydrite rocks (Gorleben-Bank, z3OSM) in a high-strain domain of the Gorleben salt dome, Germany. Zeitschrift der Deutschen Gesellschaft für Geowissenschaften 165:49-62

Muehlberger WR, Clabaugh PS (1968) Internal structure and petrofabrics of Gulf Coast salt domes. In: Brawnstein J, O’Brien GD (eds) Diapirism and diapirs, 8th edn. AAPG, Tulsa, pp 90-99

Nadoll P, Sosnicka M, Kraemer D, Duschl F (2019) Post-Variscan structurally-controlled hydrothermal $\mathrm{Zn}-\mathrm{Fe}-\mathrm{Pb}$ sulfide and $\mathrm{F}-\mathrm{Ba}$ mineralization in deep-seated Paleozoic units of the North German Basin: a review. Ore Geol Rev 106:273-299

Peach C, Spiers C, Trimby P (2001) Effect of confining pressure on dilatation, recrystallization, and flow of rock salt at $150{ }^{\circ} \mathrm{C}$. J Geophys Res Solid Earth 106:13315-13328

Pennock G, Drury M, Peach C, Spiers C (2006) The influence of water on deformation microstructures and textures in synthetic $\mathrm{NaCl}$ measured using EBSD. J Struct Geol 28:588-601

Plein E (1993) Bemerkungen zum Ablauf der-paläogeographischen Entwicklung im Stefan und Rotliegend des Norddeutschen Beckens. Geologisches Jahrbuch A 131:99-116

Pollok L, Hammer J, Musmann P (2020) Salinarstrukturen-Entstehung, Außenformen und Internbau. In: Paul J, Heggemann H (eds) Stratigraphie von Deutschland XII-Zechstein. Schriftenreihe der Deutschen Gesellschaft für Geowissenschaften, Münster, pp 159-193

Raith AF, Strozyk F, Visser J, Urai JL (2016) Evolution of rheologically heterogeneous salt structures: a case study from the NE Netherlands. Solid Earth 7:67-82. https://doi.org/10.5194/ se-7-67-2016

Reinhold K, Hammer J (2016) Steinsalzlager in den salinaren Formationen Deutschlands. Zeitschrift der Deutschen Gesellschaft für Geowissenschaften 167:167-190
Renard F, Dysthe D, Feder J, Bjørlykke K, Jamtveit B (2001) Enhanced pressure solution creep rates induced by clay particles: Experimental evidence in salt aggregates. Geophys Res Lett 28:1295-1298

Richter-Bernburg G (1955) Über salinare Sedimentation. Zeitschrift der deutschen geologischen Gesellschaft 105:593-645

Roberts NM, Rasbury ET, Parrish RR, Smith CJ, Horstwood MS, Condon DJ (2017) A calcite reference material for LA-ICP-MS U-Pb geochronology. Geochem Geophys Geosyst 18:2807-2814

Rodon S, Littke R (2005) Thermal maturity in the Central European Basin system (Schleswig-Holstein area): results of 1D basin modelling and new maturity maps. Int J Earth Sci 94:815-833

Rosen M (1994) The importance of groundwater in playas: a review of playa classification and the sedimentology and hydrology of playas. Geol Soc Am Spec Pap 289:1-18

Rowan MG, Urai JL, Fiduk JC, Kukla PA (2019) Deformation of intrasalt competent layers in different modes of salt tectonics. Solid Earth 10:987-1013

Schléder Z (2006) Deformation mechanisms of naturally deformed rock salt. Dissertation, RWTH Aachen University

Schléder Z, Urai JL (2005) Microstructural evolution of deformationmodified primary halite from the Middle Triassic Röt Formation at Hengelo, The Netherlands. Int J Earth Sci 94:941-955

Schmalholz SM, Mancktelow NS (2016) Folding and necking across the scales: a review of theoretical and experimental results and their applications. Solid Earth 7:1417-1465. https://doi. org/10.5194/se-7-1417-2016

Schmidt Mumm A, Wolfgramm M (2004) Fluid systems and mineralization in the north German and Polish basin. Geofluids 4:315-328

Secor DT (1965) Role of fluid pressure in jointing. Am J Sci 263:633-646

Siemann MG, Schramm M (2000) Thermodynamic modelling of the $\mathrm{Br}$ partition between aqueous solutions and halite. Geochim Cosmochim Acta 64:1681-1693

Siemeister G (1969) Primärparagenese und Metamorphose des Ronneberglagers nach Untersuchungen im Grubenfeld Salzdethfurth. Beihefte zum Geologischen Jahrbuch 62:1-22

Stollhofen $\mathrm{H}$ et al (2008) Upper Rotliegend to early Cretaceous basin development. In: Littke R, Bayer U, Gajewski D, Nelskamp S (eds) Dynamics of complex intracontinental basins. The Central European basin system. Springer, Heidelberg, pp 181-210

Subkommission Perm-Trias (SKPT) (2011) Beschlüsse der Deutschen Stratigraphischen Kommission 1991-2010 zu Perm und Trias von Mitteleuropa. Zeitschrift der deutschen geologischen Gesellschaft 162:1-18

Ter Heege J, De Bresser J, Spiers C (2005) Rheological behaviour of synthetic rocksalt: the interplay between water, dynamic recrystallization and deformation mechanisms. J Struct Geol 27:948-963

Thiemeyer N, Zulauf G, Mertineit M, Linckens J, Pusch M, Hammer J (2016) Microfabrics and 3D grain shape of Gorleben rock salt: constraints on deformation mechanisms and paleodifferential stress. Tectonophysics 676:1-19

Trimby P, Drury M, Spiers C (2000) Misorientations across etched boundaries in deformed rocksalt: a study using electron backscatter diffraction. J Struct Geol 22:81-89

Urai J, Spiers C (2007) The effect of grain boundary water on deformation mechanisms and rheology of rocksalt during long-term deformation. In: Wallner M, Lux K-H, Minkley W, Hardy H (eds) Proceedings of the 6th conference on the mechanical behavior of salt. Taylor \& Francis Group, London, pp 149-158

Urai JL, Spiers C, Zwart H, Lister G (1986) Weakening of rock salt by water during long-term creep. Nature 324:554-557

Urai J, Spiers C, Peach C, Franssen RC, Liezenberg JL (1987) Deformation mechanisms operating in naturally deformed halite rocks as deduced from microstructural investigations. Geol Mijnbouw $66: 165-176$ 
Van Wees J-D et al (2000) On the origin of the southern Permian Basin, central Europe. Mar Pet Geol 17:43-59

Warren JK (2016) Evaporites: a geological compendium. Springer, Switzerland

Warsitzka M, Kley J, Jähne-Klingberg F, Kukowski N (2016) Dynamics of prolonged salt movement in the Glückstadt Graben (NW Germany) driven by tectonic and sedimentary processes. Int J Earth Sci 106:131-155. https://doi.org/10.1007/s00531-016-1306-3

Woodhead JD, Hergt JM (2001) Strontium, neodymium and lead isotope analyses of NIST glass certified reference materials: SRM 610, 612, 614. Geostand Newsl 25:261-266

Wüstefeld P, Hilse U, Lüders V, Wemmer K, Koehrer B, Hilgers C (2017) Kilometer-scale fault-related thermal anomalies in tight gas sandstones. Mar Pet Geol 86:288-303

Závada P, Desbois G, Urai J, Schulmann K, Rahmati M, Lexa O, Wollenberg U (2015) Impact of solid second phases on deformation mechanisms of naturally deformed salt rocks (Kuh-e-Namak,
Dashti, Iran) and rheological stratification of the Hormuz Salt Formation. J Struct Geol 74:117-144

Zubtsov S, Renard F, Gratier J-P, Guiguet R, Dysthe DK, Traskine V (2004) Experimental pressure solution compaction of synthetic halite/calcite aggregates. Tectonophysics 385:45-57

Zulauf G, Zulauf J, Bornemann O, Kihm N, Peinl M, Zanella F (2009) Experimental deformation of a single-layer anhydrite in halite matrix under bulk constriction. Part 1: geometric and kinematic aspects. J Struct Geol 31:460-474. https://doi.org/10.1016/j. jsg.2009.01.013

Zulauf G, Zulauf J, Bornemann O, Brenker F, Höfer H, Peinl M, Woodland A (2010) Experimental deformation of a single-layer anhydrite in halite matrix under bulk constriction. Part 2: microfabrics and deformation mechanisms. J Struct Geol 32:264-277. https:// doi.org/10.1016/j.jsg.2009.12.001 